\title{
A lower Coniacian ammonite fauna from the Cauvery Basin, Tamil Nadu, south-east India
}

\author{
W. J. Kennedy and A.S. Gale $\mathrm{b}^{\mathrm{a} *}$
}

${ }^{a}$ Oxford University Museum of Natural History, Parks Road, Oxford OX1 3PW and Department of Earth Sciences, South Parks Road, Oxford OX1 3AN.

e-mail: jim.kennedy@oum.ox.ac.uk

b*Department of Earth and Environmental Sciences, University of Portsmouth, Portsmouth PO1 3QL. e-mail: andy.gale@port.ac.uk

*Corresponding author

\section{ABSTRACT}

A shell bed in the upper part of the Anaipadi Formation of the Trichiopoly Group near the villages of Pilimisai and Koothur in the Cauvery Basin, Tamil Nadu, south India yielded an abundant ammonite fauna assigned to the lower part of the Kossmaticeras (Kossmaticeras) theobaldianum Zone and to the lower Coniacian. The ammonite association of this interval in the Cauvery Basin is dominated by Mesopuzosia, Damesites, and Kossmaticeras (Kossmaticeras) species. The fauna is: Phylloceras (Hypophylloceras) masiaposensis (Collignon, 1956), Phyllopachyceras sp. , Tetragonites epigonus Kossmat, 1895, Gaudryceras (Gaudryceras) mite (Hauer, 1866), Mesopuzosia gaudama (Forbes, 1846), Damesites sugata (Forbes, 1846), Kossmaticeras (Kossmaticeras) theobaldianum (Stoliczka, 1865), K. (K.) recurrens( Kossmat, 1897, K. (K.) jonesi Collignon, 1965, Menabonites anapadensis (Kossmat, 
1898), Lewesiceras sp., Placenticeras cf. kaffrarium Etheridge, 1904, Glyptoxoceras sp., and Scalarites sp.

Keywords:

Ammonites

Cretaceous

Coniacian

Cauvery Basin

Tamil Nadu

India

\section{Introduction}

Ammonites from the Cretaceous of south India were described as early as the 1820s (Bowdich, 1822; Lamarck, 1822; see Casey 1961, p.2; Kennedy and Klinger 1978, p. 292; Hoffmann in Klein et al. 2009, p. 296). The presence of rich faunas in the environs of Puducherry (formerly Pondicherry) was documented by Kaye (1840, 1842a, b), Cunliffe (1842), M'Clelland (1842), and Campbell (1842), and the material collected by Kaye and Cunliffe was described by Edward Forbes (1846). The stratigraphy of the Cretaceous rocks in what is now known as the Cauvery Basin in Tamil Nadu (Fig. 1) was described by Blanford (1862), and the ammonite faunas documented by Stoliczka (1863-1866), who assigned all of the planispirally coiled species to the single genus Ammonites. Stoliczka's material, together with subsequently collected material was revised by Kossmat (1895-1898), with a taxonomy that approaches current concepts. These monographs remain the benchmark publications on these faunas for a century, although individual species were revised by, for example Matsumoto and Sarkar (1966) and Indian taxa were designated type species 
of a range of genera, or made types of new species (often with scant supporting text), notably by Spath (1921 onwards). The Maastrichtian ammonites from Puducherry (Pondicherry) were revised by Kennedy and Henderson (1992a, b), and others by Kennedy and Klinger (1979) and Kennedy and Henderson (1991a, b). The present account is based on material collected by one of us (ASG) and colleagues between 2000 and 2004, as part of a NERC funded research project exploring the relationship between Mesozoic sea levels and global climate. Broad conclusions were published by Gale et al. (2002), and a comprehensive revision of the Albian through Lower Turonian ammonite and inoceramid faunas of the Puducherry Sub-Basin by Gale et al. (2019). The present account provides a description of an ammonite association in a clearly defined stratigraphic context from the lower Coniacian, and supplements that given by Walaszczyk et al. (2018). Species now know to range into the Coniacian were present in the material described already by Forbes (1846), although their provenance is problematic (Kennedy and Henderson, 1991a, b).

\section{Locality details}

The material described below comes from outcrops of the Anaipadi Formation, the upper division of the Trichinopoly Group in the Puducherry Sub-Basin of the Cauvery Basin in Tamil Nadu, south India (Figs 1, 2; see Sundaram et al., 2001 for a comprehensive review of the lithostratigraphy of the Cretaceous rocks of the Cauvery Basin; their interpretations are followed here) exposed in low cliffs bounding a dry river course, $7.5 \mathrm{~km}$ west of Ariyalur (Fig. 1B), north of the Ariyalur road near the villages of Pilimisai and Koothur, coordinates $11^{\circ} 9^{\prime} 34.3^{\prime \prime} \mathrm{N}, 79^{\circ} 00^{\prime} 27.8^{\prime \prime}$ E (Fig. 3) (this may be the locality mentioned by Tewari et al., 1996, p. 797). Several metres of calcareous sandstones of the Anaipadi Formation are exposed, with a richly fossiliferous $2.4 \mathrm{~m}$ thick concretionary unit, here termed the Pilimisai Fossil bed (Fig. 4).

The abundant fauna (specimen numbers OUM KY2210-2472; 4578-4614) is dominated by rhynchonellid and terebratulid brachiopods and largely fragmentary ammonites, together with 
fossilised wood bored by teredinid bivalves. Also present are the nautiloid Eutrephoceras, bivalves including Nicaniella trigonoides (Stoliczka, 1871), Plicatula multicostata Forbes, 1846, Neithea, Cardita, Pycnodonte, and arcoids; serpulids, echinoid spines, a solitary coral, and crustacean fragments (Protocallianassa). The composition and age of the ammonite assemblage is discussed below in the concluding section.

\section{Conventions}

Dimensions are given in millimetres: $\mathrm{D}=$ diameter; $\mathrm{Wb}=$ whorl breadth; $\mathrm{Wh}=$ whorl height; $\mathrm{U}=$ umbilicus; $\mathrm{c}=$ costal dimension; ic $=$ intercostal dimension. Figures in parentheses are dimensions as a percentage of the diameter. The suture terminology is that of Korn et al. (2003): E = external lobe; $\mathrm{A}=$ adventive lobe (= lateral lobe, L, of Kullmann and Wiedmann 1970); $\mathrm{U}=$ umbilical lobe; $\mathrm{I}=$ internal lobe. The systematics of Wright (1996) is followed here.

\section{Repositories of specimens}

BMNH: The Natural History Museum, London

OUM: Oxford University Museum of Natural History.

MNHN: Muséum national d'Histoire naturelle, Paris.

\section{Systematic palaeontology}

Order Ammonoidea Zittel, 1884 
Suborder Phylloceratina Arkell, 1950

Superfamily Phylloceratoidea Zittel, 1884

Family Phylloceratidae Zittel, 1884

Subfamily Phylloceratinae Zittel, 1884

Genus Phylloceras Suess, 1866

Type species: Ammonites heterophyllus J. Sowerby, 1820, p. 119, pl. 226, by monotypy.

Subgenus Hypophylloceras Salfeld, 1924

Type species: Phylloceras onoense Stanton, 1895, p. 74, by monotypy.

Phylloceras (Hypophylloceras) masiaposensis (Collignon, 1956)

Figs 6a-g

1956 Hyporbulites masiaposensis Collignon, p. 18, pl. 1, fig. 7; text-fig. 3.

2009 Hyporbulites masiaposensis Collignon, 1956; Klein et al., pp. 90, 92 (with full synonymy).

2015 Phylloceras (Hypophylloceras) masiaposensis Collignon, 1956; Kennedy et al., p. 443, textfigs $6,16 \mathrm{c}, \mathrm{d}$. 
Types: The holotype, by original designation ("grand exemplaire choisi comme type": Collignon, 1956, p. 18) is MNHN. F. R00438, the original of Collignon 1956, p. 18, pl. 1, fig.7, from the upper Turonian of Masiaposa, Belo-sur- Tsiribihina, Madagascar. There are several paratypes, from both the upper Turonian and lower Coniacian of Masiaposa, Beantaly, and Analabe.

Material: Three specimens, OUM KY2410, 2411 and 2465.

\section{Dimensions:}

\begin{tabular}{|c|c|c|c|c|c|}
\hline & $\mathrm{D}$ & $\mathrm{Wb}$ & $\mathrm{Wh}$ & $\mathrm{Wb}: \mathrm{Wh}$ & $\mathrm{U}$ \\
\hline OUM KY2410 & $63.5(100)$ & $25.6(40.3)$ & $40.0(63.0)$ & 0.64 & $\sim 2.4(\sim 3.8)$ \\
\hline
\end{tabular}

Description: The present material comprises phragmocone fragments with whorl heights of 22.8 to $40.6 \mathrm{~mm}$, retaining recrystallized and limonitized shell. Coiling is very involute, the umbilicus minute. The umbilical wall is flat and outward-inclined, the umbilical shoulder narrowly rounded, producing a distinctive crater-like circumbilical pit. The whorl section is compressed, with a whorl breadth to height ratio of 0.65 in the smallest specimen (OUM KY2465) and 0.64 in the largest specimen (OUM KY2410). The inner and middle flanks are flattened and feebly convergent, the outer flanks feebly convex and convergent, the ventrolateral shoulders and venter broadly rounded. The inner flanks are smooth; delicate crowded lirae appear below mid-flank, and strengthen progressively across the flanks, ventrolateral shoulders and venter. They are feebly prorsiradate at mid-flank, flexing back on the outer flanks and ventrolateral shoulders to pass straight across the venter. The sutures are not seen. 
Discussion: The crater-like circumbilical depression combined with lack of ornament on the innermost flanks distinguishes masiaposensis from all other species referred to the genus.

Occurrence: Upper Turonian of the southern Corbières, Aude, France; upper Turonian and Coniacian of Madagascar; lower Coniacian of Tamil Nadu, south India.

Genus Phyllopachyceras Spath, 1925a

Type species: Ammonites infundibulum d'Orbigny, 1841, p. 131, pl. 39, figs 4, 5, by the original designation of Spath, 1925a, p. 101.

\section{Phyllopachyceras sp.}

Figs 5; 6K, L

Material: A single specimen, OUM KY2274.

Description: The specimen is a partially exfoliated phragmocone comprising a nucleus $19 \mathrm{~mm}$ in diameter and a $180^{\circ}$ sector of the succeeding whorl with a maximum preserved whorl height of 25 $\mathrm{mm}$. Coiling is very involute, the umbilicus tiny, the umbilical shoulder broadly rounded, the whorl section compressed, the whorl breadth to height ratio 0.79 , the flanks flattened and subparallel, the ventrolateral shoulders broadly rounded, the venter feebly convex. The internal mould is smooth; 
the partially exfoliated shell has traces of transverse ornament on the venter. The suture (Fig. 5) is deeply and intricately subdivided, with large, narrow-stemmed E/A, and deep, bifid A, the folioles phylloid.

Discussion: The suture line indicates the specimen to be a phylloceratid, the whorl section Phyllopachyceras; it is specifically indeterminate.

Suborder Lytoceratina Hyatt, 1889

Superfamily Tetragonitoidea Hyatt, 1900

Family Tetragonitidae Hyatt, 1900

Subfamily Tetragonitinae Hyatt, 1900

Genus Tetragonites Kossmat, 1895

Type species: Ammonites timotheanus Pictet, 1847, p. 295, pl. 2, fig. 6; pl. 3, figs 1, 2, by the original designation of Kossmat, 1895, p. 131 (35).

Tetragonites epigonus (Kossmat, 1895)

Fig. 6H-J, P-R

1865 Ammonites Timotheanus Stoliczka (non Pictet), p. 146, pl. 73, fig. 5. 
1895 Lytoceras (Tetragonites) epigonum Kossmat, p. 135 (39), pl. 17 (3), fig. 4.

1968 Epigoniceras epigonum Kossmat; Sastry et al., p. 14, pl. 4, figs 3, 4.

2009 Tetragonites epigonus (Kossmat, 1895); Klein et al., pp. 228, 232 (with full synonymy).

Type: The lectotype, by the subsequent designation of Kennedy and Klinger, 1977, p. 166, is the original of Kossmat, 1895, p. 135 (39), pl. 17 (3), fig. 4, from the Trichinopoly Group of Varagur, Tamil Nadu.

Material: Two specimens, OUM KY 2423- 4.

\section{Dimensions:}

\begin{tabular}{|c|c|c|c|c|c|}
\hline & $\mathrm{D}$ & $\mathrm{Wb}$ & $\mathrm{Wh}$ & $\mathrm{Wb}: \mathrm{Wh}$ & $\mathrm{U}$ \\
\hline OUM KY 2424 & $52.1(100)$ & $24.8(47.6)$ & $25.1(48.2)$ & 0.99 & $12.7(24.4)$ \\
\hline
\end{tabular}

Description: OUM KY2424 (Fig. 6H, I) is a $180^{\circ}$ whorl sector with a maximum preserved diameter of $52.1 \mathrm{~mm}$ and a maximum preserved whorl height of $24.8 \mathrm{~mm}$; OUM KY2423 (Fig. 6P-R) is a $120^{\circ}$ whorl sector with a maximum preserved whorl height of $36.6 \mathrm{~mm}$. Both retain recrystallized shell. Coiling is involute, the deep umbilicus comprising around $24 \%$ of the diameter; $60 \%$ approximately of the previous whorl is covered. The umbilical wall is flattened and outwardinclined, the umbilical shoulder quite narrowly rounded. The whorl section is as wide as high, the flanks very feebly convex, the outer flanks feebly convergent, the ventrolateral shoulders broadly rounded, the venter broad and feebly convex. The only ornament preserved is distant, delicate, 
narrow collar ribs that precede narrow constrictions, concave across the umbilical wall and straight and prorsiradiate across the flanks; their course on ventrolateral shoulders and venter cannot be established, nor their frequency.

Discussion: The present specimens differ in no significant respects from the lectotype (Kossmat, 1895, p. 135 (39), pl. 17 (3), fig. 4). See Kennedy and Klinger (1977, p. 165 et seq.).

Occurrence. The species ranges from Turonian to Campanian, with records from Tamil Nadu in south India, Madagascar, northern KwaZulu-Natal in South Africa, Angola, the Antarctic Peninsula, southern Patagonia, Chile, British Columbia, Japan, northern Spain, southern France, and Romania.

Family Gaudryceratidae Spath, 1927

Subfamily Gaudryceratinae Spath, 1927

Genus and Subgenus Gaudryceras de Grossouvre, 1894

Type species: Ammonites mitis Hauer, 1866, p. 305, pl. 2, figs 3, 4, by the subsequent designation of Boule et al., 1906, p. 183 (11).

Gaudryceras (Gaudryceras) mite (Hauer, 1866)

Figs 6M-O, S, T; 7A-G 
1866 Ammonites mitis Hauer, p. 305, pl. 2, figs 3, 4.

2009 Gaudryceras mite (Hauer, 1866); Klein et al., pp. 173, 184 (with synonymy).

2017 Gaudryceras mite (Hauer, 1866); Summesberger et al., p. 15 (with additional synonymy).

Type: The holotype, by monotypy, is no. 1866/01/3 in the collections of the Geological Survey of Austria, the original of Hauer, 1866, p. 305, pl. 2, figs 3, 4, and probably from the Upper Turonian Gosau Group of Strobl/Weissenbach, Austria. It was refigured by Kennedy and Summesberger (1979, pl. 1, figs 1-4) and Summesberger and Zorn (2012, pl. 4, fig. 4).

Material: Eighteen specimens, OUM KY2275-2285; 2438-44.

Description: The material consists of nuclei up to $38 \mathrm{~mm}$ in diameter and phragmocone fragments with whorl heights of up to $49 \mathrm{~mm}$. Coiling is very evolute, serpenticone, the shallow umbilicus comprising up to $50 \%$ of the diameter in juveniles, the low umbilical wall convex. The whorl section varies from subcircular to slightly compressed in the nuclei, the flanks, ventrolateral shoulders and venter broadly rounded. Where recrystallized shell is preserved, ornament is of crowded lirae that arise at the umbilical seam. They are straight to very feebly concave on the umbilical wall, feebly concave on the umbilical shoulder, prorsiradiate and feebly flexuous on the flanks: convex on the inner flank and concave on the outer flank and ventrolateral shoulder, and pass across the venter in the feeblest of convexities. The lirae increase by bifurcation on the midand outer flank. Periodic widely spaced constrictions (Fig. 7D), are preceded by a stronger collar rib or ribs in some specimens, well seen in OUM KY2297. The largest fragment, OUM KY 2275 (Fig. 
$6 \mathrm{M}-\mathrm{O})$, has particularly well-preserved lirae, and the internal mould preserves the infilling of the large septal lobe (Fig. 6O).

Discussion: See revisions in Kennedy and Summesberger (1979) and Summesberger and Kennedy (1996). The most important synonym of Gaudryceras mite is G. varagurense Kossmat, 1895 (p. 122 (26), pl. 17 (3), fig. 9; pl. 18 (4), fig. 2), originally described from the Trichinopoly Group of Varagur.

Occurrence: The species ranges from Turonian to lower Campanian. The geographic distribution extends from Austria to Poland, France, northern Spain, Romania, Eastern Cape Province and KwaZulu-Natal in South Africa, Madagascar, Tamil Nadu, Japan, Sakhalin, and California.

Suborder Ammonitina Hyattt, 1889

Superfamily Desmoceratoidea Zittel, 1895

Family Desmoceratidae Zittel, 1895

Subfamily Puzosiinae Spath, 1922

Genus Mesopuzosia Matsumoto, 1954

Type species: Mesopuzosia pacifica Matsumoto, 1954, p. 82, pl. 14, fig. 1; pl. 15, figs 1, 2; pl. 16, figs 1-3, by the original designation of Mastsumoto, 1954, p. 79. 
Mesopuzosia gaudama (Forbes, 1846)

Figs $8 \mathrm{~A}-\mathrm{O}$

1846 Ammonites Gaudama Forbes, p. 113, pl. 10, fig. 3.

1991a Mesopuzosia gaudama (Forbes, 1846); Kennedy and Henderson, p. 891, text-figs 1.1-1.4 (with synonymy).

2011 Puzosia (Puzosia) gaudama (Forbes, 1846); Klein and Vašiček, pp. 66, 74 (with additional synonymy).

2018 Mesopuzosia gaudama (Forbes, 1846); Walaszczyk et al., p. 672, text-figs 7, 8.

Type: The holotype, by monotypy, is BMNH C51065, the original of Forbes, 1846, p. 113, pl. 10, fig. 3; it was refigured by Kennedy and Henderson, 1991a, text-fig. 1.1, 1.2. Forbes stated that the specimen was from Vridachellum (now Verdachellum) in Madras State, but it is probably from some other locality, as discussed by Blanford (1862, p. 146) and Sastry et al. (1968).

Material: Seventy seven specimens, OUM KY2351-2409; 2460-2464.

Dimensions:

\begin{tabular}{|l|l|l|l|l|l|}
\hline & $\mathrm{D}$ & $\mathrm{Wb}$ & $\mathrm{Wh}$ & $\mathrm{Wb}: \mathrm{Wh}$ & $\mathrm{U}$ \\
\hline OUM KY2365 & $31.7(100)$ & $8.25(26.0)$ & $11.6(36.6)$ & 0.7 & $8.7(27.4)$ \\
\hline OUM KY 2358 & $61.8(100)$ & $20.1(32.5)$ & $26.5(42.9)$ & 0.76 & $19.1(30.9)$ \\
\hline
\end{tabular}




\begin{tabular}{|l|l|l|l|l|l|}
\hline OUM KY 2460 & $63.5(100)$ & $21.1(33.2)$ & $29.2(46.0)$ & 0.72 & $19.9(31.3)$ \\
\hline OUM KY2351 & $87.1(1000$ & $26.8(30.8)$ & $38.4(44.1)$ & 0.70 & $25.3(29.0)$ \\
\hline
\end{tabular}

Description: Specimens are preserved as both internal moulds and with recrystallized, sometimes limonitized shell material. Coiling is moderately evolute, with around 50-55\% of the previous whorl covered. The shallow umbilicus comprises around $30 \%$ of the diameter, the low umbilical wall convex, the umbilical shoulder broadly rounded. The whorl section is compressed oval, with measured whorl breadth to height ratios of between 0.70 and 0.76 , the greatest breadth below midflank. The inner flanks are feebly convex, the outer flanks flattened, the ventrolateral shoulders broadly rounded, the venter very feebly convex. The most striking feature of internal moulds is the widely separated constrictions $60^{\circ}$ (Fig. 8A) to $90^{\circ}$ (Fig 8I) apart. They are narrow, straight and prorsiradiate on the inner to mid-flank, sweeping forwards and concave on the outer flank, projecting forwards on the ventrolateral shoulder, and crossing the venter in a feebly acute chevron with a rounded apex. The inner flanks are near-smooth; delicate ribs that parallel the constrictions are conspicuous on the outer flank, ventrolateral shoulders and venter; they number between an estimated 23-24 in individuals with the most widely separated constrictions (Fig. 8A), and as few as 10 in those with more closely spaced constrictions (Fig. 7I). Where replaced shell is preserved (Fig. $8 \mathrm{C}-\mathrm{F})$, the ribs are much more conspicuous, the constrictions less so, and associated with a strengthened collar rib (Fig. 8C). There are two body chamber fragments, OUM KY2352 and 2355 (Fig. 8J, K, L, O), with a maximum preserved whorl height of $48 \mathrm{~mm}$ in OUM KY 2355 (Fig. 8JL). The constrictions are succeeded by a strong collar rib, the other ribs strong on outer flanks, ventrolateral shoulders and venter, crossing the latter in a broad convexity. The suture is deeply and intricately subdivided, with trifid $\mathrm{E} / \mathrm{A}$ and a retracted suspensive lobe. 
Discussion: The present material is interpreted as a single variable species, variation expressed in the frequency of constrictions, and the number of ribs between successive constrictions. The holotype is a pathological individual, as is indicated by the asymmetry of the ventral ribbing (Kennedy and Henderson, 1991a, text-fig. 1.2), the ribbing out of phase on the two flanks. In spite of this, the flank ornament of the least-deformed side corresponds to that of the larger of the present specimens.

Occurrence: Lower Coniacian of Tamil Nadu; upper Turonian and Coniacian of Madagascar.

Genus Damesites Matsumoto, 1942

Type species: Desmoceras damesi Jimbo, 1894, p. 172, pl. 1, figs 2, 3; ICZN Opinion 555, 1959.

Damesites sugata (Forbes, 1846)

Fig. 9A-I

1846 Ammonites Sugata Forbes, p. 113, pl. 10, figs 2a-c.

1864 Ammonites sugata Forbes; Stoliczka, p. 60, pl. 32, figs 4-6; pl. 33, figs 1, 2.

1898 Desmoceras sugata Forbes; Kossmat, p. 111 (176), pl. 18 (24), fig. 11; pl. 19 (25), fig.1).

1989 Damesites sugata (Forbes, 1846); Haggart, p. 195, pl. 8.4, figs 14-23 (with additional synonymy).

1991b Damesites sugata (Forbes, 1846); Kennedy and Henderson, p. 471, text-figs 1, 2. 
2013 Damesites sugata (Forbes, 1846); Kennedy and Klinger, p. 44, text-figs 7a-j (with additional synonymy).

2018 Damesites sugata (Forbes, 1846); Walaszczyk et al., p. 672, text-figs 9a, b, f.

Types: The lectotype, designated by Spath (1921, p. 47) is BMN C22647, the original of Forbes, 1846, pl. 10, figs 2a-c, refigured by Kennedy and Henderson 1991b, text-fig. 1a, b and Kennedy and Klinger, 2013, text-fig. 7D, E) There are three paralectotypes, BMNH C22675 (of which BMNH C3561a is a further fragment) and BMNH 24196a, b, while BMNH C3561b may be a further paralectotype. The type material is said to be from Vridachellum (now Verdachellum), Madras State, south India, but may be from some other locality as discussed by Blanford (1862, p. 146).

Material: Ninety eight specimens, OUM KY 2218-2269, 2270 (collective of 10 specimens); 2271 (collective of 6 specimens); 2272 (collective of 10 specimens); 2466-2472.

\section{Dimensions:}

\begin{tabular}{|c|c|c|c|c|c|}
\hline & $\mathrm{D}$ & $\mathrm{Wb}$ & $\mathrm{Wh}$ & $\mathrm{Wb}: \mathrm{Wh}$ & $\mathrm{U}$ \\
\hline OUM KY2471 & $25.7(100)$ & $12.1(47.1)$ & $14.5(56.4)$ & 0.83 & $-(-)$ \\
\hline OUM KY 2470 & $33.4(100)$ & $13.9(41.6)$ & $18.6(55.7)$ & 0.74 & $3.22(9.6)$ \\
\hline OUM KY2469 & $37.1(100)$ & $15.5(41.8)$ & $21.4(57.7)$ & 0.72 & $3.8(10.2)$ \\
\hline OUM KY2218 & $59.2(100)$ & $27.4(46.3)$ & $35.0(59.1)$ & 0.78 & $7.4(12.5)$ \\
\hline
\end{tabular}

Description: All of the specimens are phragmocones that range up to just over $59 \mathrm{~mm}$ in diameter, and retain worn, recrystallized shell. Coiling is very involute, the tiny, deep umbilicus comprising 
up to $12 \%$ of the diameter, the umbilical wall feebly convex, the umbilical shoulder quite narrowly rounded. The whorl section is compressed, with flattened inner flanks, feebly convex outer flanks and ventrolateral shoulders and a feebly convex venter with a well-developed blunt siphonal keel where shell is preserved, but weaker on internal moulds. The worn surface of the shell is smooth. The sutures are not seen.

Discussion: See Haggart (1989, p. 195), and Kennedy and Klinger (2013, p.45), who review differences from other species referred to the genus.

Occurrence: Coniacian to Campanian, Tamil Nadu in south India, Madagascar, Eastern Cape Province of South Africa, Angola, south-eastern France, Austria?, British Columbia, Canada, and Washington State and California in the USA.

Family Kossmaticeratidae Spath, 1922

Subfamily Kossmaticeratinae Spath, 1922

Genus and subgenus Kossmaticeras de Grossouvre, 1901

Type species: Ammonites theobaldianus Stoliczka, 1866, p. 161, pl. 87, figs 1-3, by the subsequent designation of Diener, 1925, p. 96.

Kossmaticeras (Kossmaticeras) theobaldianum (Stoliczka, 1865) 
Figs 9M, N; 10K-S

1865 Ammonites Theobaldianus Stoliczka, p. 161, pl. 78, figs 2, 3.

1897 Holcodiscus Theobaldianus Kossmat, p. 35 (142); typische Form, p. 36 (143); pl. 7 (18), fig. 5; pl. 8 (19), fig. 1; Varietät; non grobberipte Varietat p. 36 (143); Varietät mit einfach nach vorwärts geneigten Einschnürungen p. 36 (143), pl. 7 (18), fig. 4.

non 1907 Holcodiscus Theobaldianus (Stoliczka); Paulke, p. 220, pl.16 ( 7), fig. 1.

1907 Holcodiscus Theobaldianus Stoliczka; Boule et al., p.6 (26), pl. 20 (7), fig. 2.

1907 Holcodiscus Theobaldianus Stoliczka, variété; Boule et al., p. 6 (26), pl. 20 (7), fig. 3.

1954 Kossmaticras Theobaldi Stoliczka; Collignon, p. 16, pl. 1, fig.2.

1954 Kossmaticeras Theobaldi var. crassicostata Collignon, p. 17, pl.1, fig. 3; pl. 2, fig. 1.

1955a Kossmaticeras Theobaldi Stoliczka; Collignon, p. 20, pl. 1, fig. 2.

1955a Kossmaticeras Theobaldi var. crassicostata Collignon, p. 21, pl.1, fig. 3; pl. 2, fig. 1.

1955 Kossmaticeras theobaldianum paucicostatum Matsumoto, p. 147, pl. 9, figs 1, 2.

non 1956 Kossmaticeras theobaldianum (Stoliczka); Cecioni, pl. 1, fig. 6 (=Kossmaticeras (Kossmaticeras?) fasciculatum Macellari, 1998, p. 893. text-fig. 4.1)

1957 Kossmaticeras theobaldianum (Stoliczka); Wright, p. L374, text-fig. 373.5a-c.

1965a Kossmaticeras theobaldi Stol. var. crassicostata Collignon; Collignon, p. 24, pl. 423, fig. 1756; pl.174, fig. 1757.

1985 Kossmaticeras (Kossmaticeras) theobaldianum theobaldianum (Stoliczka, 1865); Kennedy and Klinger, p. 170, text-figs 2a-e.

1991a Kossmaticeras theobaldianum (Stoliczka, 1865); Matsumoto, p. 6, text-fig. 3a. 
1991b Kossmaticeras theobaldianum (Stoliczka, 1865); Matsumoto, p. 98, pl. 24, fig. 1.

1996 Kossmaticeras (Kossmaticeras) theobaldianum (Stoliczka); Wright, p. 92, text-fig. 70.1a-c. 2004 Kossmaticeras theobaldianum crassicostatum Collignon, 1954; Walaszczyk et al., p. 545; text-fig. 7Ea, Eb.

2018 Kossmaticeras (Kossmaticeras) theobaldianum (Stoliczka, 1865); Walaszczyk et al., p. 675, text-fig. 1c.

Type: Previous authors have regarded the original of Stoliczka, 1865, pl. 78, fig. 2, as the typical form of a variable theobaldianum (for example Kossmat, 1897, p. 36 (143)), but we have not noted a formal lectotype designation. Accordingly, the original of Stoliczka's pl. 78, fig. 2 is here designated lectotype. The original is in the collections of the Geological Survey of India. The original of Stoliczka's pl. 78, fig. 1 (refigured by Kossmat, 1897, pl. 7 (18), fig. 2), is the lectotype of Kossmaticeras (K.) recurrens (Kossmat, 1897) (p. 37 (141) by the subsequent designation of Matsumoto, 1991, p. 98. All of these specimens are from the neighbourhood of Anaipady.

Material: Thirty specimens, OUM KY2291, 2293, 2298-2304, 2306-7, 2309-13, 2321-4, 2335, $2337,2339,2345-50,2445$.

Description: OUM KY2315 is the largest specimen in the present collection (Fig. 9M, N); it is a $120^{\circ}$ whorl sector of two whorls of phragmocone with a maximum preserved costal whorl height of $38 \mathrm{~mm}$, the costal whorl section 0.9 , the flanks feebly convex, the inner and middle flanks subparallel, the outer flanks converging to broadly rounded ventrolateral shoulders and a feebly convex venter. Ten ribs arise at the umbilical seam. Two strengthen into well-developed bullae, and 
are the adapertural collar rib to well-developed constrictions. They are prorsiradiate, straight on the inner flank, and bifurcate on the mid- to outer flank, sweeping forwards and very feebly concave on the ventrolateral shoulders and pass straight across the venter. There are eight ribs that arise at the umbilical seam between successive bullate collar ribs; they are near-straight and prorsiradiate, strengthening progressively across the flanks. Additional ribs intercalate or bifurcate, to give a total of fifteen ribs at the ventrolateral shoulder between successive collar-ribs.

Also assigned to Kossmaticeras $(K$.$) theobaldianum are numerous more densely ribbed$ fragments (Fig. 10K-S) with whorl heights of up to $30 \mathrm{~mm}$ (OUM KY2302); OUM KY2303 is typical (Fig. 10Q-S). This $120^{\circ}$ whorl fragment retains recrystallized shell, and has a maximum preserved costal whorl height of $21.4 \mathrm{~mm}$, the costal whorl breadth and height equal. Nineteen ribs arise at the umbilical seam of the fragment, and are narrow, sharp, straight and prorsiradiate across the inner and middle flanks, very feebly concave on the ventrolateral shoulders, and near-straight across the venter. There is one well-developed constriction; it is preceded by a slightly stronger collar rib that branches four times, with a single unbranched adapertural collar rib. The ribs between the constrictions increase by intercalation and occasional branching to give a total of 34 at the ventrolateral shoulder.

The sutures are not seen.

Discussion: The difference in rib density between the two variants is striking, and matches that between individuals assigned to the species by subsequent workers. The sparcicostate variants (Fig. 9M-N) correspond to the lectotype. The densicostate variants (Fig. 10K-S) correspond, in this respect, to Kossmat's variety of theobaldianum (Varietät mit einfach nach vorwärts geneigten Einschnürungen [variety with simple forward directed (inclined) constrictions], p. 36 (143), pl. 7 (18), fig. 4). This figure was reproduced by Basse (1952, pl. 17, fig. 7) and Wright (1957, text-fig. 373, 5a-c ; 1996, text-fig 70. 1a-c). Interestingly, one of the present specimens (OUM KY2303: Fig. 
10Q-S) has the same multiple branching adapical collar rib to the constriction as does the lectotype. See Kennedy and Klinger (1985, p. 172) for further discussion.

Occurrence: Lower Coniacian, Tamil Nadu, Madagascar, KwaZulu-Natal in South Africa, and Japan.

Kossmaticeras (Kossmaticeras) recurrens Kossmat, 1897

Fig. 10A-J

1865 Ammonites Theobaldianus Stoliczka, p. 161 (pars), pl. 78, fig. 1.

1897 Holcodiscus recurrens Kossmat, p. 37 (144), pl. 7 (18), figs 2, 3.

1925 Kossmaticeras recurrens Kossmat; Diener, p. 99.

1954 Kossmaticeras recurrens Kossmat; Collignon, p. 43.

1956 Kossmaticeras recurrens Kossmat; Collignon, p. 41.

1965b Kossmaticeras recurrens (Kossmat); Collignon, p.10, pl. 380, fig. 1642.

1991a Kossmaticeras recurrens (Kossmat, 1897); Matsumoto, p.16.

1991b Kossmaticeras recurrens (Kossmat, 1897); Matsumoto, p. 98. 
Types: The lectotype, by the subsequent designation of Matsumoto (1991b, p. 98) is the original of Kossmat, 1897, p. 37 (144), pl. 7 (18), fig. 2 (=Stoliczka, 1865, pl. 78, fig. 1), housed in the collections of the Geological Survey of India; it is from the environs of Anaipandy.

Material: Ten specimens, OUM KY2289-90, 2294, 2296-7, 2314, 2336, 2338, 2247-8.

\section{Dimensions:}

\begin{tabular}{|l|l|l|l|l|l|}
\hline & $\mathrm{D}$ & $\mathrm{Wb}$ & $\mathrm{Wh}$ & $\mathrm{Wb}: \mathrm{Wh}$ & $\mathrm{U}$ \\
\hline OUM KY2296 & $51.1(100)$ & $19.4(38.0)$ & $23.5(46.00$ & 0.83 & $18.0(35.2)$ \\
\hline OUM KY2289 & $56.8(100)$ & $18.9(33.3)$ & $23.9(24.0)$ & 0.8 & $17.9(31.5)$ \\
\hline
\end{tabular}

Description: Specimens range up to $57 \mathrm{~mm}$ in diameter. The best-preserved, OUM KY2289, a phragmocone $57 \mathrm{~mm}$ in diameter (Fig. 10F-H), retains recrystallized shell, with indications of the former presence of a further $180^{\circ}$ whorl sector. Coiling is moderately evolute, with $45 \%$ of the previous whorl covered, the shallow umbilicus comprising $32 \%$ of the diameter, the umbilical wall low and flattened, the umbilical shoulder quite broadly rounded. The whorl section is compressed, the whorl breadth to height ratio 0.8 , the subparallel flanks very feebly convex, the ventrolateral shoulders broadly rounded, the venter very feebly convex. Ornament is of crowded, sharp, narrow, wiry ribs. An estimated 40 arise at the umbilical seam, and 90 at the umbilical shoulder. They are either single at the umbilical shoulder or bifurcate, increasing by bifurcation or intercalation on the flanks. They are straight and prorsiradiate on the inner and middle flanks, feebly concave on the outer flanks and ventrolateral shoulders, and cross the venter in a shallow convexity. Constrictions, feebly expressed on the surface of the replaced shell (Fig. 10C) are flanked by a branching adapical 
and single adapertural collar rib. Other specimens assigned to the species are both more finely (Fig. 10A, B), and more coarsely (Fig. 10D, E) ribbed. The sutures are not seen.

Discussion: Specimens assigned to recurrens are distinguished from densely ribbed variants of $K$. (K.) theobaldianum on the basis of their higher whorls, finer ribs and less prominent constrictions; the differences are slight.

Occurrence: Lower Coniacian of Tamil Nadu. Also recorded from the upper Turonian of Madagascar.

Kossmaticeras (Kossmaticeras) jonesi Collignon, 1965

Fig. 9J-L

1965a Kossmaticeras jonesi Collignon, p. 29, pl. 426, figs 1764-1765.

1985 Kossmaticeras jonesi Collignon, 1965; Kennedy and Klinger, p. 186, text-figs 6d, e; 12c, d.

Type: The holotype, by original designation is the original of Collignon, 1965a, pl. 426, fig. 1464, from the lower Coniacian of Collignon's gisement 745, Ankinatsy-Souromaranaia (Belo sur Tsiribihina) section, Madagascar, housed in the collections of the Universite de Bourgogne, Dijon.

Material: OUM KY2359. 


\section{Dimensions:}

\begin{tabular}{|c|c|c|c|c|c|}
\hline & $\mathrm{D}$ & $\mathrm{Wb}$ & $\mathrm{Wh}$ & $\mathrm{Wb} ; \mathrm{Wh}$ & $\mathrm{U}$ \\
\hline OUM KY2359 & $57.7(100)$ & $16.8(29.1)$ & $20.9(36.2)$ & 0.8 & $21.2(36.7)$ \\
\hline
\end{tabular}

Description: The specimen is a worn internal mould of a phragmocone, preserved in buff-coloured limestone. Coiling is moderately evolute, the shallow umbilicus comprising $36.7 \%$ of the diameter, the umbilical wall low and concave, the umbilical shoulder quite narrowly rounded as a result. The whorl section is compressed, with a whorl breadth to height ratio of 0.8 , the flanks feebly convex, the maximum whorl breadth below mid-flank, the ventrolateral shoulders broadly rounded, the venter feebly convex. The inner flanks are worn, but there are indications of blunt, narrow, prorsiradiate primary ribs arising at the umbilical shoulder, the ribs straight and prorsiradiate on the flanks, feebly concave on the ventrolateral shoulders, and crossing the venter near- transverse. There are 30 ribs at the ventrolateral shoulder of the $180^{\circ}$ sector of the outer whorl of the fragment, and three well-developed constrictions per half whorl. They are straight and prorsiradiate on the inner flank, markedly concave and prorsiradiate on the outer flank and ventrolateral shoulder, and cross the venter in a marked convexity. The constrictions are flanked by an adapical collar-rib that bifurcates on the outer flank, the adapical branch paralleling the other ribs, the adapertural paralleling the constriction : discordant and markedy prorsiradiate on the outer flank and ventrolateral shoulder. The sutures are too imperfectly preserved for description.

Discussion: The specimen is assigned to Kossmaticeras (K.) jonesi on the basis of the whorl section, density and strength of ribbing, together with the form of the constrictions and bifurcation of the adapical collar rib. 
Occurrence: Lower Coniacian of Madagascar and Tamil Nadu.

Family Pachydiscidae Spath, 1922

Genus Menabonites Houša, 1967

Type species: Pachydiscus Anapadensis Kossmat, 1898, p. 90 (155), pl. 14 (20), fig. 2, by the original designation of Houša, 1967, p. 41.

Menabonites anapadensis (Kossmat, 1898)

Fig. 11A-G

1865 Ammonites peramplus Stoliczka, p. 130, pl. 65, figs 1, 2.

1898 Pachydiscus Anapadensis Kossmat, p. 90 (155), pl. 14 (20), fig. 2.

1925 Pachydiscus anapadensis Kossmat; Diener, p. 105.

1952 Lewesiceras anapadense Kossmat; Collignon, pp. 21, 84.

1955b Lewesiceras anapadense Kossmat; Collignon, pp. 24, 77.

1967 Menabonites anapadensis (Kossmat, 1898); Houša, p. 41.

1996 Menabonites anapadensis (Kossmat); Wright, p. 101, text-fig. 79.2.

Types: When introducing the present species Kossmat referred to material cited and figured by Stoliczka as Ammonites peramplus (1865, p. 130, pl. 65, figs 1,2), a total of 14 specimens in the Collections of the Geological Survey of India, from north-west of Anaipady, and figured the suture of one of them (1898, pl. 14 (20), fig. 2); all rank as syntypes. The original of Stoliczka, 1865, pl. 65, fig. 1 is here designated lectotype. Stoliczka's original figures of the lectotype were reproduced by Wright (1996, text-fig. 79.2).

Material: Three specimens, OUM KY2419-21. 
Description: The three phragmocone fragments retain recrystallized shell, and have whorl heights of 18-27 mm. Coiling is moderately involute, the umbilicus deep, with a feebly convex umbilical wall and broadly rounded umbilical shoulder. The whorl section is depressed reniform, with the greatest breadth just outside the umbilical shoulder. The whorl breadth to height ratio is 1.2 . Widely separated primary ribs, three in the $120^{\circ}$ whorl sector of OUM KY2419 (Fig. 11A-C) arise at the umbilical seam, and strengthen across the umbilical wall, developing into strong, sharp umbilical bullae. These give rise to a strong, straight, prorsiradiate rib that links to a strong ventrolateral bulla, from which a rib or a pair of ribs project forwards and cross the venter in a broad convexity. Successive primary ribs are separated by much weaker intercalated ribs that arise on the inner flank, lack an umbilical tubercle, with some but not all developing a small ventrolateral bulla. The ventral development parallels that of the primary ribs. The exact number cannot be established because of poor preservation. The sutures are not seen.

Discussion: Poor though the preservation is, these fragments show the same basic rib pattern as the lectotype. Of other species referred to Menabonites, Ammonites prosperianus d'Orbigny, 1841) (p. 335, pl. 100, figs 3,4) is a chimaera, d'Orbigny's figure based on the whorl proportions of a Lewesiceras and the ornament of a Hyphantoceras (Kennedy and Cooper, 1977; Kennedy and Juignet, in Gauthier, 2006, p. 123). Menabonites masiaposensis (Collignon, 1952) (p. 17, pl. 1, fig. 1; 1955, p. 21, pl. 1, fig. 1) is a close ally, differing principally in the enormous size of the umbilical tubercles. Menabonites beantalyensis (Collignon, 1952) (p. 19, pl. 1, figs 2, 3; pl. 2, figs 1, 2; 1955, p. 22, pl. 1, figs 2, 3; pl. 2, figs 1,2) has constrictions on the early whorls, the ribs arising in groups from umbilical bullae, the primary and intercalated ribs of near-equal strength, rather than markedly differentiated, and lacks ventrolateral tubercles. The umbilical bullae become very strong on the outer whorl. Menabonites sornayi (Collignon, 1952) (p. 24, pl. 2, fig. 4; 1955, p. 26, pl. 2, fig. 4) has massive, very depressed whorls, widely separated ribs with smooth or near-smooth interspaces, and lacks ventrolateral tubercles. 
Occurrence: Lower Coniacian of Tamil Nadu.

Genus Lewesiceras Spath, 1939

Type species: Ammonites peramplus Mantell, 1822, p. 200, by the original designation of Spath, 1939, p. 296.

Lewesiceras sp. juv.

Fig. 7H-J

Material: Six specimens, OUM KY2426-29, 2436, 2437.

Description: Phragmocone fragments have whorl heights of up to $19 \mathrm{~mm}$; the most complete is an approximately $90^{\circ}$ whorl sector (Fig. 7I, J). The whorl section is very depressed reniform in intercostal section. The costal whorl breadth to ratio is 1.5 to 1.6. The umbilical wall is flattened and outward-inclined. There are no flanks. The venter is very broad, and evenly rounded. The best preserved fragments have massive umbilical bullae that give rise to pairs of coarse ribs that are initially prorsiradiate and concave, then sweeping forwards and crossing the venter in a broad convexity. The interspace between the pairs of ribs in strengthened into a prominent constriction. There are three or four weaker long intercalated ribs between successive bullae. The poorly preserved sutures are deeply incised, with narrow-stemmed saddles and a deep, trifid E/A.

Discussion: Of described species, the closest comparisons are with Lewesiceras vaju (Stoliczka, 1865) (p. 132, pl. 65, fig. 3), the original of Stoliczka's figured specimen refigured by Kossmat (pl. 14 (20), fig. 4). This syntype is much larger than the present fragments, and such as is visible of the 
inner whorls has slightly weaker bullae, while the outer whorls have a compressed section. They may be conspecific, but definitive evidence is lacking.

Occurrence: Lower Coniacian, Tamil Nadu.

Superfamily Hoplitoidea H. Douvillé, 1890

Family Placenticeratidae Hyatt, 1900

Genus Placenticeras Meek, 1876

Type species: Ammonites placenta DeKay, 1828 (p. 278), by the original designation of Meek, 1876, p. 46.

Placenticeras sp., cf. kaffrarium Etheridge, 1904

Fig. $11 \mathrm{H}-\mathrm{K}$

Compare:

1904 Placenticeras kaffrarium Etheridge, p. 89, pl. 3, fig. 16.

1989 Placenticeras kaffrarium Etheridge, 1904; Klinger and Kennedy, p. 268, text-figs 9-14a, 1920, 22-99.

2018 Placenticeras kaffrarium Etheridge, 1904; Walaszczyk et al., p. 679, text-figs 12-14.

Material: Four specimens, OUM KY2415-8. 
Description: The material comprises crushed phragmocone fragments with whorl heights of up to $47 \mathrm{~mm}$. Coiling is very involute, the small umbilicus shallow, with a flattened, outwards-inclined umbilical wall and narrowly rounded umbilical shoulder. The whorl section is very compressed, the whorl breadth to height ratio 0.45 , the greatest breadth at the umbilical shoulder. The flanks are flattened and convergent. The ventrolateral shoulders sharp, the venter feebly concave between. Ornament is restricted to long, low clavi, perched on the ventrolateral shoulder, and alternating in position on either side of the venter. The sutures are not seen.

Discussion: Slight as the material is, it corresponds well with the compressed variants of the highly variable Placenticeras kaffrarium: Placenticeras umkwelanense Etheridge, 1904 (p.89, pl. 3, figs 17-20; see Klinger and Kennedy 1989, text-fig. 20a-c etc.).

Occurrence: As for material. Placenticeras kaffrarium ranges from upper Turonian (Madagascar) to middle Coniacian (northern KwaZulu-Natal in South Africa), with additional records from the Bagh Beds of central India, the Alphard Group off Cape Province, South Africa, Angola, and, possibly, Namibia and south-eastern Algeria.

Suborder Ancyloceratina Wiedmann, 1966

Superfamily Turrilitoidea Gill, 1871

Family Diplomoceratidae Spath, 1926

Subfamily Diplomoceratinae Spath, 1926 
Type species: Hamites rugatus Forbes, 1846, p. 117, pl. 11, fig. 2, by the original designation of Spath, 1925, p. 30.

\section{Glyptoxoceras sp.}

Text-fig. 12C, D

Material: OUM KY2286.

Description: The specimen is a $34 \mathrm{~mm}$ long fragment from the adapical end of the body chamber, preserving the adaperturalmost septal face at the adapical end. The maximum preserved whorl height is $22 \mathrm{~mm}$. The whorl section is compressed ovoid, the dorsum more narrowly rounded than the venter, the costal whorl breadth to height ratio 0.7 approximately (preservation is defective). The rib index is 11 , the ribs effaced and feebly concave across the dorsum, strengthening across the dorsolateral margin, equal, straight and prorsiradiate across the flanks, strengthening across the ventrolateral shoulders and passing straight across the venter.

Discussion: The simple ornament, lack of flared ribs and constrictions indicate Glyptoxoceras, a genus not previously recorded from the Coniacian of south India, and one of the earliest records of the genus. 
Occurrence: Lower Coniacian, Tamil Nadu.

Genus Scalarites Wright and Matsumoto, 1954

Type species: Helicoceras scalare Yabe, 1904, p. 9, pl. 3, figs 2, 3, by the original designation of Wright and Matsumoto, 1954, p. 115.

\section{Scalarites sp.}

Fig. 12A, B

Material: OUM KY2422.

Description: The specimen is a $33 \mathrm{~mm}$ long phragmocone fragment retaining recrystallized shell. The maximum preserved whorl height is $25.7 \mathrm{~mm}$; the whorl breadth to height ratio 0.8 , the whorl section oval, the dorsum more narrowly rounded than the venter. The rib index is 10 . The ribs are narrow, crowded, transverse on the dorsum, strengthening across the dorsolateral margin, straight and feebly prorsiradiate on the flanks, and passing straight across the venter. There are two constrictions on the fragment, the adapertural flanking rib strengthened on the ventrolatral shoulders and venter, giving a distinctive appearance to the ventral view (Fig. 12B). The sutures are not seen. 
Discussion: Slight as the material is, the combination of simple, even ribbing and periodic constrictions with flanking adapertural collar rib indicate Scalarites. The closest comparison is with Scalarites turoniense (Schlüter, 1872) (p. 103, pl. 32, figs 4-5; see Kaplan and Kennedy, 1994, p. 58, pl. 37, figs 1, 5-6; pl. 39, figs 1, 2, 4, 9; Wiese, 2000, p. 414, pl. 3, figs 1,2, 4-8, 10, 11) known from the lower Coniacian of Germany, the Czech Republic, and Kazakhstan. The genus has not been previously recorded from south India.

Occurrence: Lower Turonian, Tamil Nadu.

\section{Conclusions: composition and age of thePilimisai fauna.}

\subsection{Composition}

The generic/subgeneric composition of the 285 ammonites in the Pilmisai fauna is as follows: Phylloceras (Hypophylloceras): $6(2 \%)$

Phyllopachyceras: $1(0.3 \%)$

Tetragonites: $2(0.7 \%)$

Gaudryceras (Gaudryceras): 18 (6.3\%)

Mesopuzosia: 77 (27\%)

Damesites: 98 (34\%)

Kossmaticeras (Kossmaticeras): 68 (24\%)

Menabonites: 4 (1.4\%)

Lewesiceras: $6(2.1 \%)$

Placenticeras: 4 (1.4\%)

Glyptoxoceras sp.: $1(0.3 \%)$

Scalarites sp.: $1(0.3 \%)$ 
What is unique to the assemblage is the dominance of Desmoceratoidea (88.5\%): we know of no other mid-Cretaceous ammonite assemblage that approaches this composition.

\subsection{Age}

The Pilimisai fauna corresponds to the zone of Kossmaticeras theobaldianum of authors (see below) in its various manifestations; the age is discussed here in terms of the substage and zonal sequences developed in Western Europe (Fig. 13). The discussion is complicated by the fact that there is no agreed Global boundary Stratotype Section and Point for the base of the Coniacian Stage. The recommendation of the Second International Symposium on Cretaceous Stage Boundaries (Kauffman et al., 1996) was the first occurrence of the inoceramid bivalve Cremnoceramus rotundatus (sensu Tröger, 1967, non Fiege, 1930), which is a junior synonym of Cremnoceramus deformis erectus (Meek, 1877). A specimen of Forresteria (Harleites) petrocoriensis (Coquand, 1859), index species of the lowest Coniacian ammonite zone was described from the upper Turonian Mytiloides scupini Zone in the Vistula valley (Poland) (Kennedy and Walaszczyk , 2004), $3.1 \mathrm{~m}$ below the first occurrence of Cremnoceramus deformis erectus. On this basis the proposed inoceramid-defined base of the stage lies within the petrocoriensis Zone (Fig. 13), and there is no ammonite marker for the base of the stage (see Walaszczyk and Cobban, 2000, p. 4 for further discussion).

Ayyasami and Rao (1984) recognised successive zones of Romaniceras ornatissimum, Lewesiceras anapadense and Kossmaticeras theobaldianum in the Trichinopoly Group; Phansalkar (1983, p. 180) had already recorded ornatissimum from the basal Trichinopoly Group, and Ayyasami and Rao (1980a, b; 1984, p. 225) recorded it from the basal shell limestones of the Group. This species is well-dated in Western Europe, where it occurs in the middle of the middle Turonian Collignoniceras woollgari Zone (Fig.13). Romaniceras (R.) deverianum (d'Orbigny, 
1841) was also recorded from the basal Trichinopoly Group by Phansalkar (1983, p. 178); this is a lower upper Turonian species.

The presence of Peroniceras (Peroniceras) dravidicum (Kossmat, 1895) (p. 190 (94), pl. 22 (9), fig. 3, = Ammonites sub-tricarinatus d'Orbigny of Stoliczka, 1865, p. 54, pl. 31, fig. 3; see synonymy in Klinger and Kennedy, 1984, p. 170, text-figs 29-42 (with full synonymy)) in the upper part of the Trichinopoly Group (Ayyasami and Rao, 1984) permits a correlation with the middle Coniacian Peroniceras tridorsatum Zone of the European sequence (Fig. 13; Kennedy, 1984, p. 26). Ayyasami and Rao (1980) recognized a dravidica Zone overlying a Kossmaticeras theobaldianum Zone at the top of the Trichinopoly Group, and indicated that Peroniceras (P.) dravidicum cooccurred with Kossmaticeras theobaldianum, suggesting, in 1984 (p. 227) that there should rather be an upper, dravidicum Subzone of the theobaldianum Zone. On this basis their theobaldianum Zone spans the lower/middle Coniacian boundary.

Further evidence for the age of the present fauna, which lacks Peroniceras, and is thus lower Coniacian, comes from the sequence in Madagscar. Collignon (1965a) recognized the following zonal sequence:

Coniacien supérieur, zone à Prionocycloceras guyabanum et Gauthiericeras margae

Coniacien moyen; zone à Kossmaticeras theobaldi et Barroisiceras onilahyense

Coniacien inférieur: zone à Peroniceras dravidicum

This zonal sequence is clearly anomalous compared to those recognized elsewhere, and this was clearly demonstrated by the detailed study of the Manasoa section on the Onilahy River in southwest Madagascar by Walaszczyk et al. (2004), where Collignon's zone à Kossmaticeras theobaldi et Barroisiceras onilahyense was shown to be possibly uppermost Turonian and lower Coniacian, rather than middle Coniacian. A critical species for dating the Pilimisi fauna is the bivalve Tethyoceramus madagascariensis Heinz, 1933 (OUM KY2435: identified by Professor I. 
Walaszczyk, Warsaw) from the Pilimisai section This is the index species of the lowest Coniacian inoceramid zone recognized in the Onilahy River section where it first appears in the upper part of the range of Barroisiceras onilahyense. The Pilimisai fauna is thus lower Coniacian, the absence of Peroniceras from a collection of over 280 ammonites indicating that it corresponds to the lower part of the overall range of the index species in the upper part of the Anaipadi Formation.

\section{Acknowledgements}

This project was supported by an NERC grant, GR3/12516, to ASG entitled: 'Were Mesozoic sealevels under global climate control?', which supported fieldwork in Tamil Nadu in 2000-2004. Dr Vijay Phansalkar provided initial guidance in the field, where ASG was assisted by Dr Jan Hardenbol, Dr Ben Hathway, Research Assistant during the project, who generated section and logs, and former students Dr Kitty Thomas, Dr Evan Laurie, Kate Richardson, and Bryony Williams, who assisted with fossil collecting. The support of the staff of the Oxford University Museum of Natural History, and David Sansom of the Department of Earth Sciences, Oxford, is gratefully acknowledged; we also thank Herbert Klinger, Irek Walaszczyk, and Bernard Joly for their assistance, and an anonymous referee for a meticulous review of the manuscript.

\section{References}

Arkell, W. J. 1950. Jurassic Ammonoidea. Journal of Paleontology 26, 860-861.

Ayyasami, K., Rao, B. R. J. 1980a. Goniomya from the Trichinopoly Group, Upper Cretaceous, Tamil Nadu. Journal of the Geological Society of India 21, 354-357.

Ayyasami, K., Rao, B. R. J. 1980b. On the possible faunal break at the contact of Trichinopoly and Ariyalur 
Groups in the Cretaceous Succession of Tiruchirapalli district, Tamilnadu. Proceedings of the VII Indian Colloquium on Microplaeontology and Stratigraphy, 1-5.

Ayyasami, K., Rao, B. R. J. 1984. Observations on the biostratigraphic zones of the Trichinopoly Group (Upper Cretaceous), Tamilnadu. Proceedings of the X Indian Colloquium on Micropalaeontology and Stratigraphy, 223-230.

Basse, E. 1952. Ammonoidea s. str., 581-688 in Piveteau, J. (ed.) Traité de Paléontologie, 2. Masson, Paris.

Blanford, H.F. 1862. On the Cretaceous and other rocks of the South Arcot and Trichinopoly Districts, Madras. Memoirs of the Geological Survey of India 4, 1-217.

Boule, M., Lemoine, P., Thévenin, A. 1906-1907. Paléontologie de Madagascar III Céphalopodes crétacés des environs de Diego-Suarez. Annales de Paléontologie 1 (1906), 173-192 (1-20); 2 (1907), 1-56 (21-76).

Bowdich, T. E. 1822. Elements of conchology including the fossil genera of the animals, 1, univalves. Printed by J. Smith and sold by Treuttel and Würtz, London and Paris. $73+7$ p.

Campbell, [Captain]. 1842. Correspondence. Calcutta Journal of Natural History 2, 276-279.

Casey, R. 1960. A monograph of the Ammonoidea of the Lower Greensand, part 1. Monograph of the Palaeontographical Society, xxxvi $+1-44$.

Cecioni, G. 1956. Significato della ornamentazione in alcune Kossmaticeratidae della Patagonia. Rivista Italiana di Paleontologia e Stratigrafia 62, 3-10.

Collignon, M. 1952. Ammonites néocrétacées du Menabe (Madagascar) II - Les Pachydiscidae. Travaux 
du Bureau Géologique de Madagascar 41, 114 p.

Collignon, M. 1954. Ammonites néocrétacées du Menabe (Madagascar) III - Les Kossmaticeratidae. Travaux du Bureau Géologique de Madagascar 62, 59 p.

Collignon, M. 1955a. Ammonites néocrétacées du Menabe (Madagascar) III - Les Kossmaticeratidae. Annales Géologiques du Service des Mines de Madagascar 22, 54 p.

Collignon, M. 1955b. Ammonites néocrétacées du Menabe (Madagascar) II - Les Pachydiscidae. . Annales Géologiques du Service des Mines de Madagascar 21, 98 p.

Collignon, M. 1956. Ammonites néocrétaces du Menabe (Madagascar) IV. Les Phylloceratidae. V. Les Gaudryceratidae. VI. Les Tetragonitidae. Annales Géologiques du Service des Mines de Madagascar 23, $106 \mathrm{p}$.

Collignon, M. 1965a. Atlas des fossiles caracteristiques de Madagascar (Ammonites), XIII (Coniacien). Service Géologique, Tananarive. vii +88 p.

Collignon, M. 1965a. Atlas des fossiles caracteristiques de Madagascar (Ammonites), XII (Turonien). Service Géologique, Tananarive. iv $+82 \mathrm{p}$.

Coquand, H. 1859. Synopsis des animaux et des végétaux fossiles observés dans la formation crétacée du Sud-Ouest de la France. Bulletin de la Société Géologique de France (2) 16, 945-1023.

Cunliffe, C.E. 1842. Correspondence. Calcutta Journal of Natural History 2, 113-115.

DeKay, J.E. 1828. Report on several fossil multilocular shells from the state of Delaware: with observations 
on a second specimen of the new fossil genus EURYPTERUS. Annals of the Lyceum of Natural History of New York 2, 273-279.

Diener, C. 1925. Ammonoidea neocretacea. Fossilium Catalogus (1: Animalia) 29, 244 p.

Etheridge, R. 1904. Cretaceous fossils of Natal. 1. The Umkwelane Hill Deposit. Second report of the Geological Survey of Natal and Zululand, 69-93.

Fiege, K. 1930. Über die Inoceramen des Oberturon mit besonderer Berücksichtigung der in Rheinland und Westfalen vorkommenden Formen. Palaeontographica 73, 31-47.

Forbes, E. 1846. Report on the fossil Invertebrata from southern India, collected by Mr. Kaye and Mr. Cunliffe. Transactions of the Geological Society of London (2) 7, 97-174.

Gale, A.S., Hardenbol, J., Hathway, B., Kennedy, W.J., Young, J.R., Phansalkar, V. 2002. Global correlation of Cenomanian (Upper Cretaceous) sequences: evidence for Milankovitch control on sea level. Geology 30, 291-294.

Gale, A. S., Kennedy, W. J., Walaszczyk, I. 2019.Upper Albian, Cenomanian and Lower Turonian stratigraphy, ammonite and inoceramid bivalve faunas from the Cauvery Basin, Tamil Nadu, South India. Acta Geologica Polonica 69, 161-338.

Gauthier, H. 2006. Révision Critique de la Paléontologie Française d'Alcide d’Orbigny, 6, Céphalopodes Crétacés. Backhuys, Leiden. 1-292 +1-662 p.

Gill, T. 1871. Arrangement of the Families of Mollusks. Smithsonian Miscellaneous Collections 227, xvi + $49 \mathrm{p}$. 
Grossouvre, A. de 1894. Recherches sur la craie supérieure, 2, Paléontologie. Les ammonites de la craie supérieure. Mémoires pour server à l'explication de la Carte Géologique détaillée de la France, 264 p. (misdated 1893).

Haggart, J. W. 1989. New and revised ammonites from the Upper Cretaceous Nanaimo Group of British Columbia and Washington State. Geological Survey of Canada Bulletin 396, 181-221.

Hauer, F. R. von. 1866. Neue Cephalopoden aus den Gosaugebilden der Alpen. Sitzungsberichte der kaiserlichen Akademie der Wissenschaften in Wien Mathematisch-Naturwissenschaftliche Classe 53, 300$308(1-9)$.

Heinz, R. 1933. Inoceramen von Madagaskar und ihre Bedeutung für die Kreide-Stratigraphie. Zeitschrift der Deutschen Geologischen Gesellschaft 85, 241-259.

Houša, V. 1967. Lewesiceras Spath (Pachydiscidae, Ammonoidea) from the Turonian of Bohemia. Sborník Geologických Věd Paleontologie řada P. svazek 9, 7-50 .

Hyatt, A. 1889. Genesis of the Arietidae. Smithsonian Contributions to Knowledge 673, xi +239 p.

Hyatt, A. 1900. Cephalopoda, p.502-604 in Zittel, K. A. Von 1896-1900, Textbook of Palaeontology, transl. Eastman, C.R. Macmillan, London and New York.

Jimbo, K. 1894. Beiträge zur Kenntniss der Fauna der Kreideformation von Hokkaido. Paläontologische Abhandlungen n.s. 2, 147-194.

Kaplan, U., Kennedy, W.J. 1994. Ammoniten des westfälischen Coniac. Geologie und Paläontologie in Westfalen 31, 1-155. 
Kauffman, E. G. (compiler), Kennedy, W. J., Wood, C. J. 1996. The Coniacian stage and substage Boundaries. Bulletin de l'Institut Royal des Sciences Naturelles de Belgique. Sciences de la Terre 66, supplement, 81-94.

Kaye, C. T. 1840. Observations on the fossiliferous beds near Pondicherry, and in the district of South Arcot. Madras Journal of Literature and Science 12, 37-42.

Kaye, C.T. 1842a. Observations on the fossiliferous beds near Pondicherry, and in the district of South Arcot. Calcutta Journal of Natural History 2, 225-230.

Kaye, C.T. 1842b. Further observations on the fossiliferous beds near Pondicherry, in continuation of a paper which appeared in the Madras Journal of Literature and Science for July 1840. Calcutta Journal of Natural History 2, 235-237.

Kennedy, W.J. 1984. Systematic palaeontology and stratigraphic distribution of the ammonite faunas of the French Coniacian. Special Papers in Palaeontology 31, vi + 1-160.

Kennedy, W. J., Bilotte, M., Melchior, P. 2015. Turonian ammonite faunas from the southern Corbières, Aude, France. Acta Geologica Polonica 65, 437-494.

Kennedy, W.J., Cooper, M.R. 1977. Ammonites prosperianus d'Orbigny, 1841 (Cretaceous Ammonoidea) is a chimaera. Neues Jahrbuch für Geologie und Paläontologie, Monatsheft 1977, 36-46.

Kennedy, W.J., Henderson, R.A. 1991a. Revision of Ammonites Gaudama Forbes, 1846 (Cretaceous Ammonoidea). Journal of Paleontology 65, 891-893. 
Kennedy, W.J., Henderson, R.A. 1991b. A note on Ammonites Sugata Forbes, 1846. Neues Jahrbuch für Geologie und Paläontologie, Monatsheft 1991, 470-476.

Kennedy, W.J. Henderson, R.A. 1992a. Non-heteromorph ammonites from the Upper Maastrichtian of Pondicherry, South India. Palaeontology 35, 381-442.

Kennedy, W. J. , Henderson, R.A. 1992b. Heteromorph ammonites from the Upper Maastrichtian of Pondicherry, South India. Palaeontology 35, 693-731.

Kennedy, W.J., Klinger, H.C. 1977. Cretaceous faunas from Zululand and Natal, South Africa. The ammonite family Tetragonitidae Hyatt, 1900. Annals of the South African Museum 73, 149-197.

Kennedy, W.J., Klinger, H.C. 1978. Cretaceous faunas from Zululand and Natal, South Africa. The ammonite family Lytoceratidae Neumayr, 1875. Annals of the South African Museum 74, 257-333.

Kennedy, W.J., Klinger, H.C. 1979. Cretaceous faunas from Zululand and Natal, South Africa. The ammonite family Gaudryceratidae. Bulletin of the British Museum (Natural History) Geology 31, 121-174.

Kennedy, W.J., Klinger, H.C. 1985. Cretaceous faunas from Zululand and Natal, South Africa. The ammonite family Kossmaticeratidae Spath, 1922. Annals of the South African Museum 95, 165-231.

Kennedy, W. J., Klinger, H. C. 2013. Cretaceous faunas from Zululand and Natal, South Africa. The ammonite Subfamily Desmoceratinae Zittel, 1895. African Natural History 9, 39-54.

Kennedy, W.J., Summesberger, H. 1979. A revision of Ammonites mitis Hauer and Ammonites glaneggensis Redtenbacher from the Gosau Beds (Upper Cretaceous) of Austria. Beiträge zur Paläontologie von Österreich 6, 71-87. 
Kennedy,W.J., Walaszczyck, I. 2004. Forresteria (Harleites) petrocoriensis (Coquand, 1859), from the Upper Turonian Mytiloides scupini Zone of Slupia Nadbrzena, Poland. Acta Geologica Polonica 54, 55-59.

Klein, J., Hoffmann, R., Joly, B., Shigeta, Y., Vašiček, Z. 2009. Lower Cretaceous Ammonites IV Boreophylloceratoidea, Phylloceratoidea, Lytoceratoidea, Tetragonitoidea, Haploceratoidea including Upper Cretaceous representatives. Fossilium Catalogus 1: Animalia 146, 416p.

Klein, J., Vašiček, Z. 2011. Lower Cretaceous Ammonites V Desmoceratoidea. Fossilium Catalogus 1: Animalia 148, $311 \mathrm{p}$.

Klinger, H.C., Kennedy, W.J. 1984. Cretaceous faunas from Zululand and Natal, South Africa. The ammonite subfamily Peroniceratinae Hyatt, 1900. Annals of the South African Museum 92, 113-294.

Klinger, H.C., Kennedy, W.J. 1989. Cretaceous faunas from Zululand and Natal, South Africa. The ammonite family Placenticeratidae Hyatt, 1900; with comments on the systematic position of the genus Hypengonoceras Spath, 1924. Annals of the South African Museum 98, 241-408.

Korn, D., Ebbighausen, V., Bockwinkel J., Klug, C. 2003. The A-mode ontogeny in prolecanitid ammonites. Palaeontology 46, 1123-1132.

Kossmat, F. 1895-1898. Untersuchungen über die Südindische Kreideformation. Beiträge zur Paläontologie Österreich-Ungarns und des Orients, 9 (1895): 97-203 (1-107); 11 (1897): 1-46 (108-153); 11(1898): 89-152 (154-217).

Kullmann, J., Wiedmann, J. 1970. Significance of sutures in phylogeny of Ammonoidea. University of Kansas, Paleontological Contributions 42, 1-32. 
Lamarck, J.P.B.A. de M. de 1822. Histoire naturelle des Animaux sans vertebrès, 7. Verdière, Paris. 711p.

Macellari, C. 1986. Late Campanian-Maastrichtian ammonite fauna from Seymour Island (Antarctic Peninsula). Memoir of the Paleontological Society 18, 55 p.

Mantell, G.A. 1822. The Fossils of the South Downs; or illustrations of the geology of Sussex. Lupton Relfe, London. xvi +327 p.

Matsumoto, T. 1942. A note on the Japanese Cretaceous ammonites belonging to the subfamily Desmoceratinae. Proceedings of the Imperial Academy of Japan 18, 24-29.

Matsumoto, T. 1954. Family Puzosiidae from Hokkaido and Saghalien. Memoirs of the Faculty of Science, Kyushu University, Series D, Geology. 5, 69-118.

Matsumoto, T. 1955. Family Kossmaticeratidae from Hokkaido and Saghalin. Japanese Journal of Geology and Geography 26, 115-165.

Matsumoto, T. 1991a. The mid-Cretaceous ammonites of the family Kossmaticeratidae from Japan, Part 1, general remarks. The Palaeontological Society of Japan Special Papers 33, 3-20.

Matsumoto, T. 1991b. The mid-Cretaceous ammonites of the family Kossmaticeratidae from Japan. Kossmaticeras flexuosum sp. nov. The Palaeontological Society of Japan Special Papers 33, 96-100.

Matsumoto, T., Sarkar, S.S. 1966. Utaturiceras vicinale (Stoliczka) from Southern India, p. 297-309 in Matsumoto, T., Sastry, M.V.A. and Sarkar, S.S. 1966. Notes on some Cretaceous ammonites from southern India. Memoirs of the Faculty of Science, Kyushu University, Series D, Geology 17, 295-309. 
M'Clelland, J. 1842. Revised notes on fossils, discovered by Messrs. Kaye and Cunliffe, Madras Civil Service at Seedrapett. Calcutta Journal of Natural History 2, 238-244.

Meek, F.B. 1876. A report on the invertebrate Cretaceous and Tertiary fossils of the upper Missouri country. In Hayden, F.V. Report of the United States Geological Survey of the Territories 9, lxiv +629 p.

Meek, F.B. 1877. Paleontology. United States Geological Survey Exploration of the Fortieth Parallel. 4, 1197.

Orbigny, A. d'. 1840-1842. Paléontologie française: Terrains crétacés. 1. Céphalopodes. Masson, Paris. 1120 (1840); 121-430 (1841); 431-662 (1842).

Paulcke, W. 1907. Die Cephalopoden der oberen Kreide Südpatagoniens. Berichte der Naturforschenden Gesellschaft zu Freiburg in Breisgau 15, 167-248.

Phansalkar, V.G. 1983. Some acanthoceratids from the Upper Cretaceous rocks of Trichinopoly, Tamil Nadu. Indian Society of Earth Scientists, Prof. Kelkar Memorial Volume, 173-182.

Pictet, F. J. 1847. In Pictet, F. J., Roux, W. 1847-1854. Description des mollusques fossiles qui se trouvent dans les Grès Verts des environs de Genève. Mémoires de la Société de Physique et d'Histoire Naturelle de Genève 11, 257-412.

Salfeld, H. [J.C.A]. 1924. Die Bedeutung der Konservativstämme für die Stammesentwicklung der Ammonoideen. Verlag Max Weg, Leipzig. 16 p.

Sastry, M.V.A., Rao, B.J.R., Mamgain, V.D. 1968. Biostratigraphic zonation of the Upper Cretaceous formations of Trichinopoly district, South India. Memoirs of the Geological Society of India 2, 10-17. 
Schlüter, C. 1871-1876. Cephalopoden der oberen deutschen Kreide. Palaeontographica 21, 1-24(1871); 21, 25-120, (1872); 24, 1-144 (121-264) + x (1876).

Sowerby, J. 1812-1822. The Mineral Conchology of Great Britain. The Author, London. 1, pls 1--9 (1812), pls 10-44 (1813), pls 45-78 (1814), pls 79-102 (1815); 2, pls 103-114 (1815), pls 115-150 (1816), pls 151186 (1817), pls 187-203 (1818); 3, pls 204-221 (1818), pls 222-253 (1819), pls 254-271 (1820), pls 272306 (1821); 4, pls 307-18 (1821), pls 319-83 (1822).

Spath, L.F. 1921. On Cretaceous Cephalopoda from Zululand. Annals of the South African Museum 12, 217-321.

Spath, L.F. 1922. On the Senonian ammonite fauna of Pondoland. Transactions of the Royal Society of South Africa 10, 113-147.

Spath, L. F. 1925a. Sur quelques ammonites du Gault nommés par P. Reynès. Annales du Musée d'Histoire Naturelle de Marseille 20, 95-106.

Spath, L.F. 1925b. On Senonian Ammonoidea from Jamaica. Geological Magazine 62, 28-32.

Spath, L.F. 1926. On new ammonites from the English Chalk. Geological Magazine 63, 77-83.

Spath, L. F. 1927. Revision of the Jurassic fauna of Kach (Cutch). Memoirs of the Geological Survey of India, Palaeontologica Indica, n. s., 9 memoir 2 part 1, 1-71.

Spath, L. F. 1939. Problems of ammonite nomenclature 6. The genus Pachydiscus Zittel. Geological Magazine 74, 293-296. 
Stanton, T.W. 1895. Contributions to the Cretaceous palaeontology of the Pacific Coast. The fauna of the Knoxville Beds. Bulletin of the United States Geological Survey 133, 132 p.

Stoliczka, F. 1863-1866. The fossil cephalopoda of the Cretaceous rocks of Southern India. Ammonitidae with revision of the Nautilidae etc. Memoirs of the Geological Survey of India. Palaeontologica Indica, 3 (1), 41-56 (1863); (2-5), 57-106 (1864); (6-9), 107-154 (1865); (10-13), 155-216 (1866).

Stoliczka, F. 1870-1871. Cretaceous faunas of Southern India. 3. The Pelecypoda with a review of all known genera of this class, fossil and recent, by Ferd. Stoliczka, Ph. D., F. G. S. \& c. Memoirs of the Geological Survey of India, Palaeontologica Indica 6, 1-222 (1870); i-xxii, 223-538 (1872).

Suess, E. 1866. Über Ammoniten. Sitzungsberichte der Akademie der kaiserlichen Wissenschaften, Mathematisch-Naturwissenschaftliche Classe, Wien, 52 (for 1865) Abteilung 1, 71-89.

Summesberger, H. Kennedy, W. J., Skoumal, P. 2017. Early and middle Santonian Cephalopods from the Gosau Group (Upper Cretaceous, Austria) 1. Nautiloidea and non-heteromorph Ammonoidea. Abhandlungen der Geologischen Bundesanstalt 71, 54-99.

Summesberger, H., Zorn, I. 2012. A catalogue of the type specimens of late Cretaceous cephalopods housed in the collections of the Geological Survey of Austria in Vienna. Jahrbuch der Geologischen Bundesanstalt 152, 101-144.

Sundaram, R., Henderson, R. A., Ayyasami, K., Stilwell, J. D. 2001 Lithostratigraphic revision and palaeoenvironmental assessment of the Cretaceous System exposed in the onshore Cauvery Basin, southern India. Cretaceous Research 22, 743 -762.

Tewari, A., Hart, M. B., Watkinson, M. P. 1996. A revised lithostratigrphic classification of the Cretaceous 
rocks of the Trichinopoly district, Cauvery Basin, southeast India. Contributions to the XV Colloquium on Micropalaeontology and Stratigraphy, $789-800$.

Tröger, K.A. 1967. Zur Paläontologie, Biostratigraphie und faziellen Ausbildung der unteren Oberkreide (Cenoman bis Turon); Teil 1, Paläontologie und Biostratigraphie der Inoceramen des Cenomans bis Turons Mitteleuropas. Abhandlungen des Staatlichen Museums für Mineralogie und Geologie zu Dresden 12, 13207.

Walaszczyk, I., Cobban, W. A. 2000. Inoceramid faunas and biostratigraphy of the Upper Turonian-Lower Coniacian of the Westerrn Interior of the United States. Special Papers in Palaeontology 64, 1-118.

Walaszczyk, I., Kennedy, W. J., Paranjape, A. R. 2018. Inoceramids and associated ammonites from the uppermost Turonian-lower Coniacian (Upper Cretaceous) of the Anaipandi-Sardamangalam region of the Cauvery Basin, south-east India. Acta Geologica Polonica 68, 663-687.

Walaszczyk, I., Marcinowski, R., Praszkier, T., Dembicz, K., Bienkowska, M. 2004. Biogeographical and stratigraphical significance of the latest Turonian and early Cconiacian inoceramid/ammonite succession of the Manasoa section on the Onilahy River, south-west Madagascar. Cretaceous Research 25, 543-576.

Wiedmann, J. 1966. Stammesgeschichte und System der posttriadischen Ammonoideen; ein Überblick. Neues Jahrbuch für Geologie und Paläontologie, Abhandlungen 125, 49-79; 127, 13-81.

Wiese, F. 2000. On some Late Turonian and Early Coniacian (Upper Cretaceous) heteromorph ammonites from Germany. Acta Geologica Polonica 50, 407-419.

Wright, C. W.1957. [Cretaceous Ammonoidea]. In Moore, R.C. (ed). Treatise on Invertebrate Paleontology. Part L, Mollusca 4, Cephalopoda Ammonoidea. Geological Society of America and 
University of Kansas Press, New York and Lawrence. xxii +490 p.

Wright, C.W. 1996. Treatise on Invertebrate Paleontology. Part L, Mollusca 4: Cretaceous Ammonoidea.(with contributions by J.H. Calloman (sic) and M.K. Howarth). Geological Society of America and University of Kansas, Boulder, Colorado and Lawrence, Kansas. $x x+362$ p.

Wright, C.W., Matsumoto, T. 1954. Some doubtful Cretaceous ammonite genera from Japan and Saghalien. Memoirs of the Faculty of Science, Kyushu University, Series D, Geology 4, 107-134.

Yabe, H. 1904. Cretaceous Cephalopoda from the Hokkaido. 2. Turrilites, Helicoceras, Heteroceras, Nipponites, Olcostephanus, Desmoceras, Hauericeras, and an undetermined Genus. Journal of the College of Science, Imperial University 20, 1-45.

Zittel, K.A. Von. 1884. Handbuch der Palaeontologie. 1, Abt. 2; Lief 3, Cephalopoda. R. Oldenbourg; Munich and Leipzig. 329-522.

Zittel, K.A. Von. 1895. Grundzüge der Palaeontologie (Palaeozoologie).. R. Oldenbourg; Munich and Leipzig. vii +972 


\section{Explanation of figures}

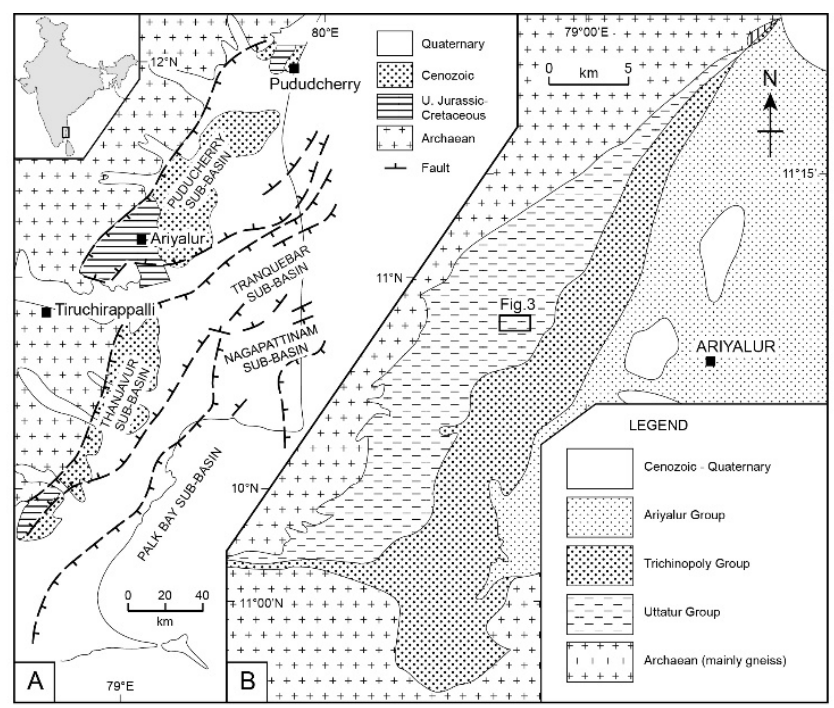

Fig. 1: A, simplified geological map of the Cauvery Basin. B, simplified geological map of a part of the Puducherry Sub-Basin; the Pilimisai. Section lies $7.5 \mathrm{~km}$ west of Ariyalur.

\begin{tabular}{|c|c|}
\hline GROUP & FORMATION \\
\hline \multirow{2}{*}{ ARIYALUR (part) } & SILLAKKUDI \\
\hline \multirow{2}{*}{ TRICHINOPOLY } & ANAIPADI \\
\cline { 2 - 2 } & KULAKKALNATTAM \\
\hline \multirow{2}{*}{ UTTATUR (part) } & KARAI \\
\hline
\end{tabular}

Fig. 2: Lithostratigraphic subdivisions of the Cretaceous succession in the Cauvery Basin. 


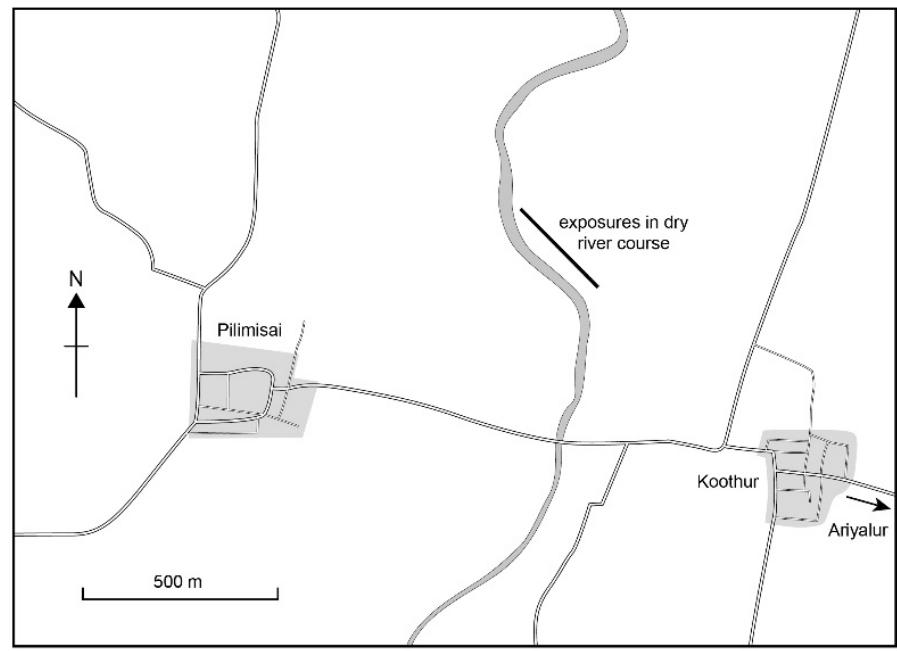

Fig. 3: Detailed locality map showing the position of the Pilimisai section.

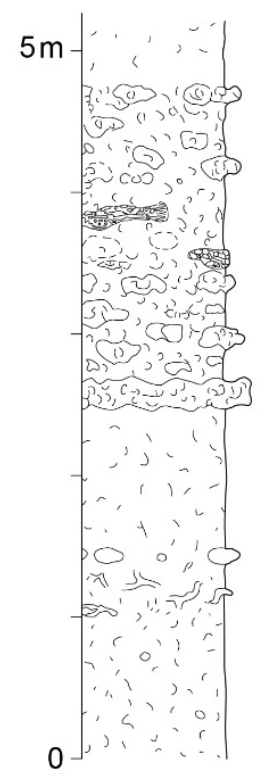

Fine sands

\section{Pilimisai Fossil Bed:}

Fine brown, ferruginous, silty sands containing soft concretions, abundant mollusc and brachiopod shells, wood bored by teredinid bivalves; fossils concentrated in stream bed.

Brachiopods most common in top $0.5 \mathrm{~m}$

Fine brown bioturbated ferruginous sands containing sparse septarian concretions; Planolites throughout, concentration of Thalassinoides in middle. No body fossils.

Fig. 4: The section in the Anapadi Formation north-east of Pilimisai. 


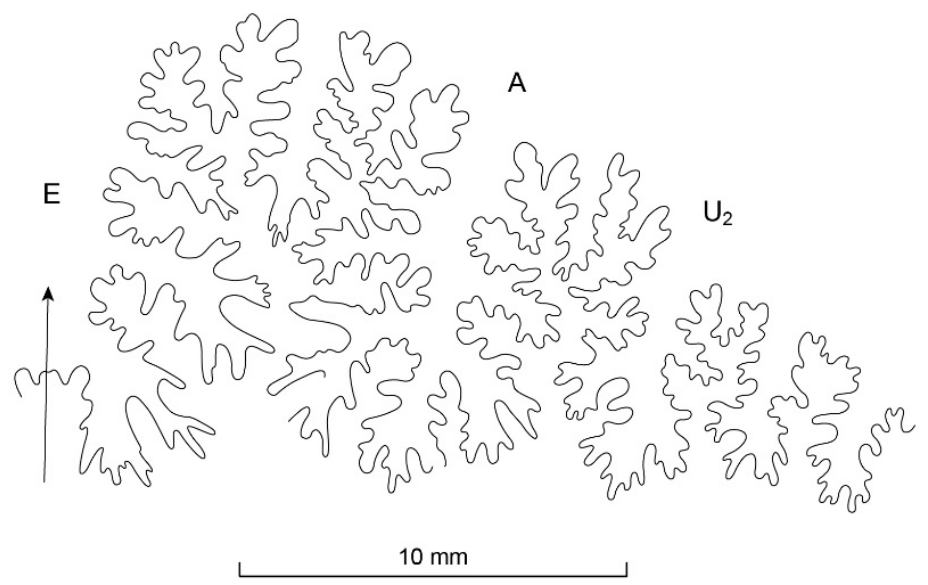

Fig. 5: Partial external suture of Phyllopachyceras sp., OUM KY2274.

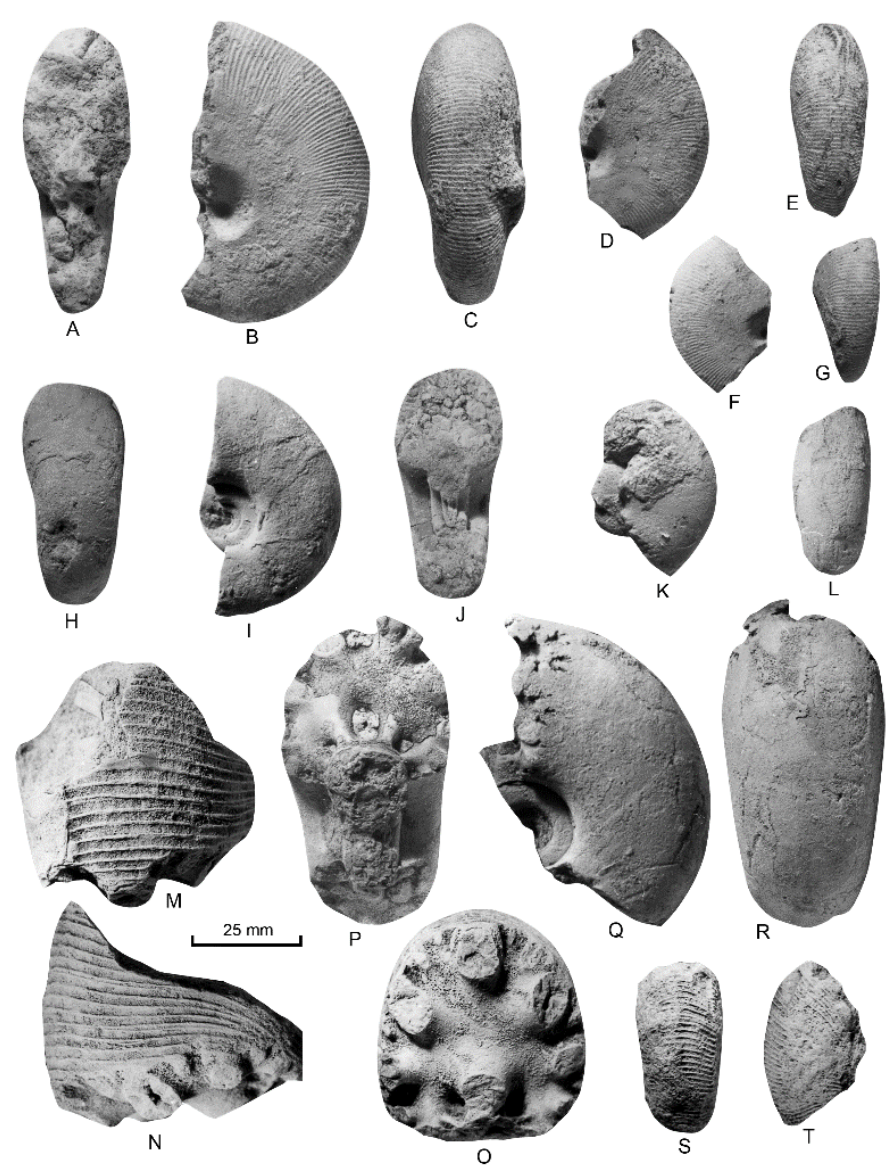

Fig. 6: A-G, Phylloceras (Hypophylloceras) masiaposensis (Collignon, 1956): A-C, OUM KY2410; D, E, OUM KY2411; F, G, OUM KY2465. H-J, P-R: Tetragonites epigonus Kossmat, 
1895: H-J, OUM KY2424; P-R, OUM KY2423. K, L: Phyllopachyceras sp.: OUM KY2247. M-O, S, T: Gaudryceras (Gaudryceras) mite (Hauer, 1866): M-O, OUM KY2275; S, T, OUM KY2441.
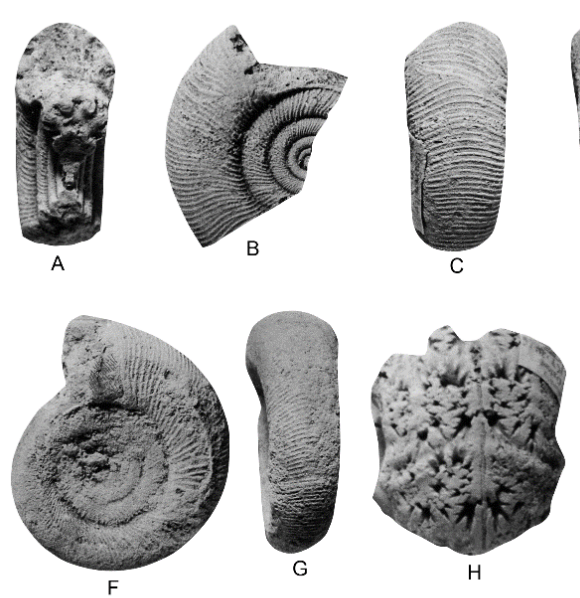

$25 \mathrm{~mm}$
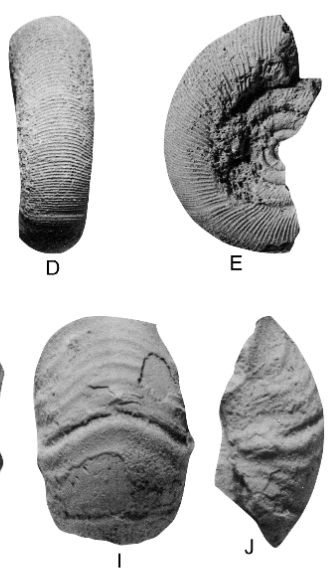

Fig. 7: A-G, Gaudryceras (Gaudryceras) mite (Hauer, 1866); A-C, OUM KY2283; D, E: OUM KY2281; F, G: OUM KY2444. H-J, Lewesiceras sp. H, OUM KY2426; I, J: OUM KY 2429. 


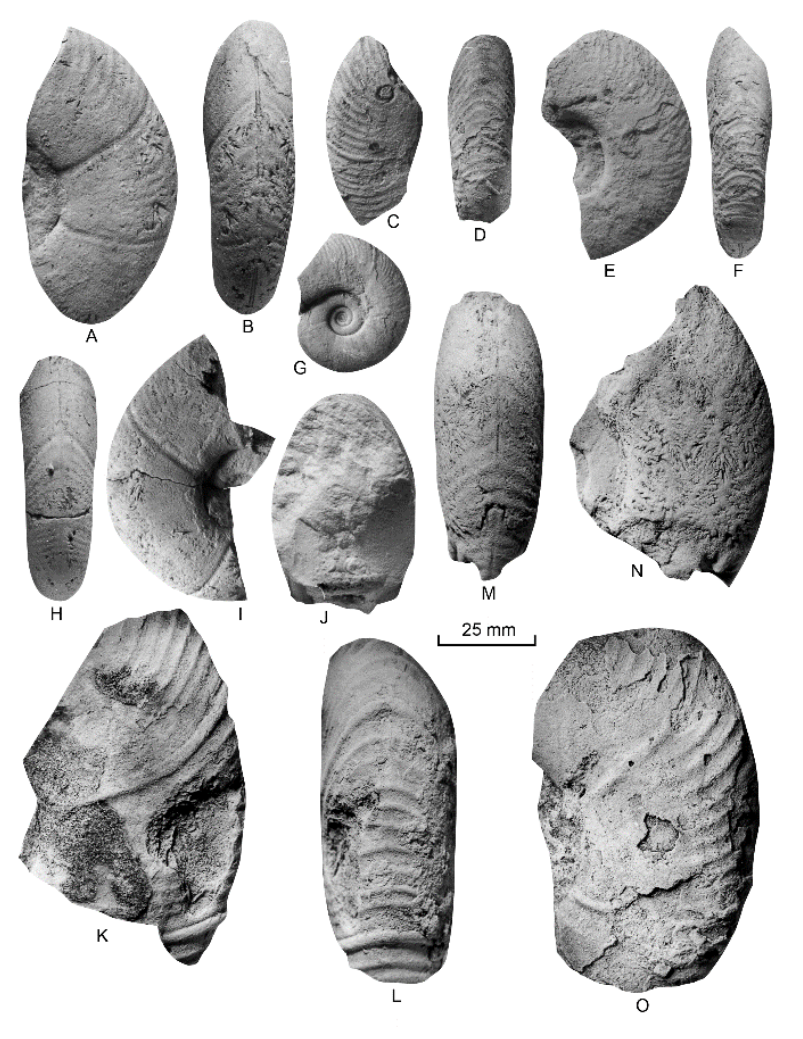

Fig. 8: Mesopuzosia gaudama (Forbes, 1846); A, B, OUM KY2357; C, D, OUM KY2383;E, F, OUM KY2360; G, OUM KY2365; H, I, OUM KY2461; J-L, OUM KY2355; M, N, OUM KY2356; O, OUM KY2352.
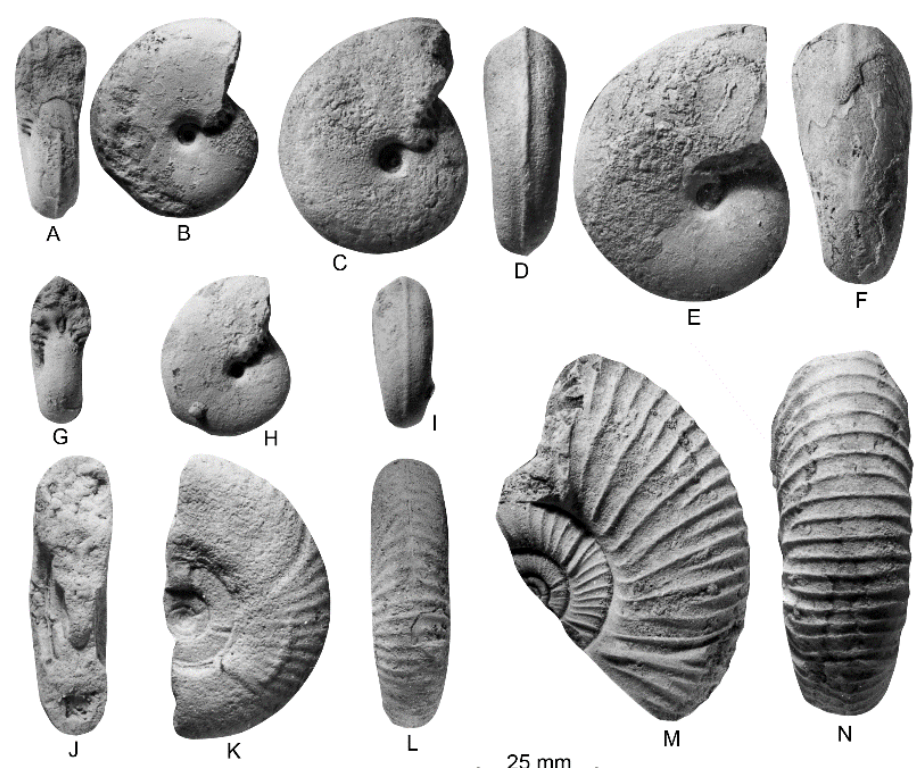

$25 \mathrm{~mm}$

Fig.9: A-I, Damesites sugata (Forbes, 1846); A, B, OUM KY2228; C, D, OUM KY2219; E, F, OUM KY2218; G-I, OUM KY2470. J-L, Kossmaticeras (Kossmaticeras ) jonesi Collignon, 1965; 
OUM KY2359. M, N, Kossmaticeras (Kossmaticeras) theobaldianum (Stoliczka, 1865); OUM KY2315.

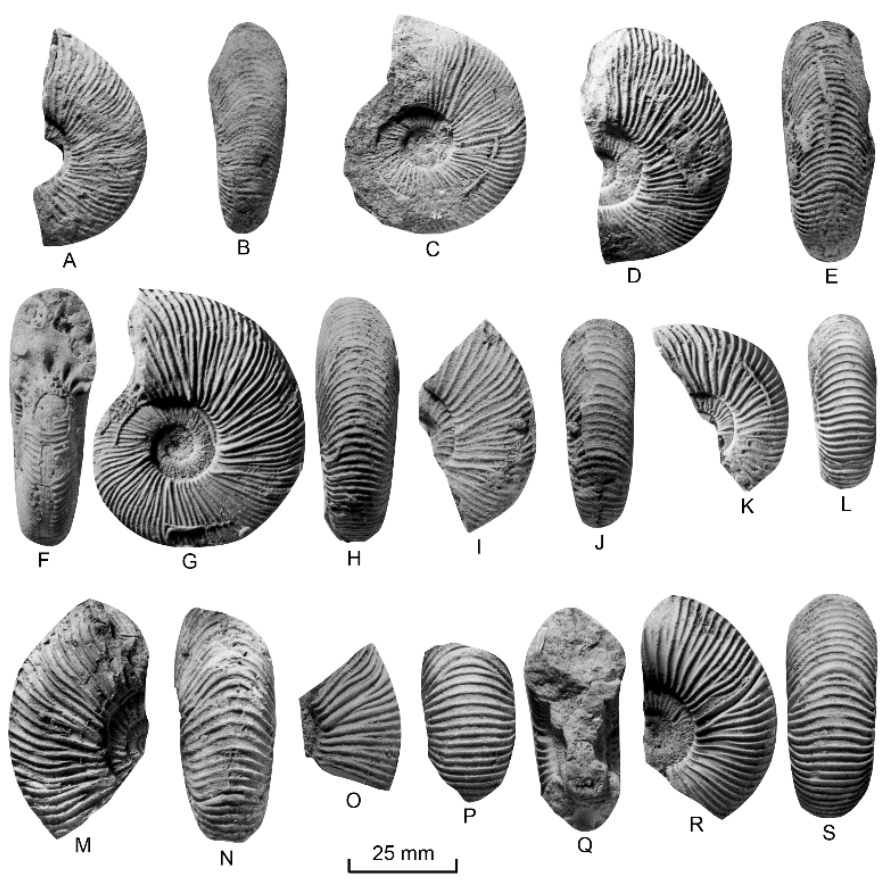

Fig. 10: A-J, Kossmaticeras (Kossmaticeras) recurrens (Kossmat, 1897); A, B, OUM KY2338; C, OUM KY2290; D, E, OUM KY2296; F-H, OUM KY2289; I, J, OUM KY2297. K-S, Kossmaticeras (Kossmaticeras) theobaldianum (Stoliczka, 1865); K, L, OUM KY2304; M, N, OUM KY2300; O,P, OUM KY2335; Q-S, OUMKY2303. 


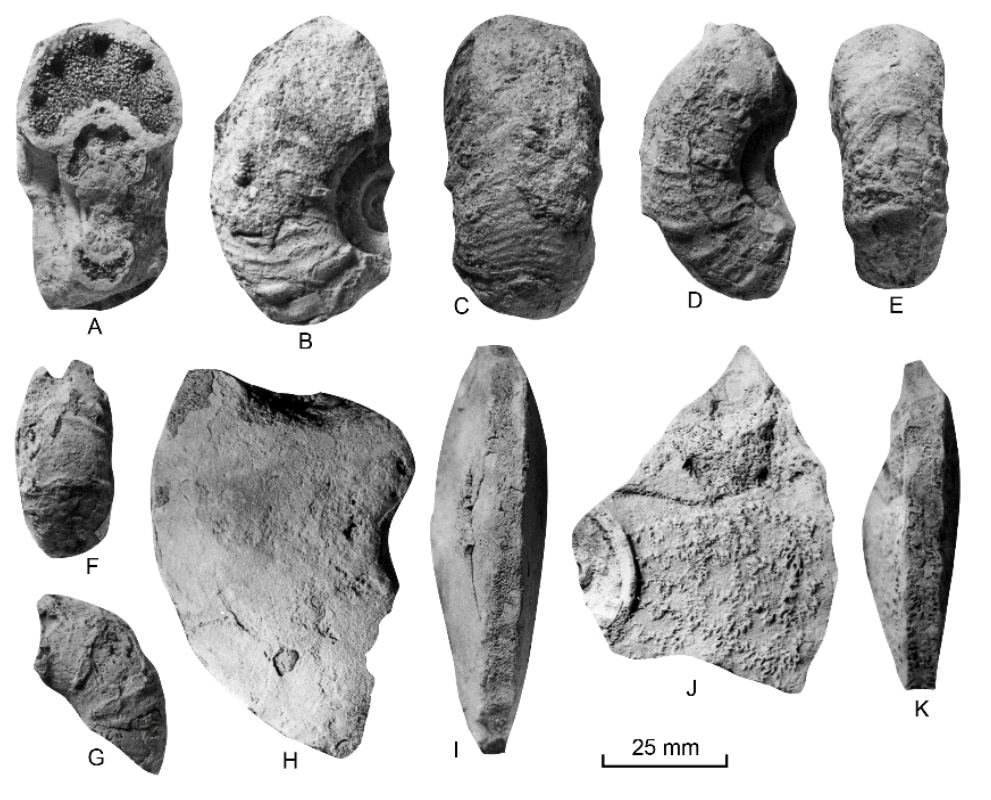

Fig. 11: A-G, Menabonites anapadensis (Kossmat, 1898); A-C, OUM KY2419; D, E, OUM KY2420; F, G, OUM KY2421. H-K, Placenticeras sp. cf. kaffrarium Etheridge, 1904; H, I, OUM KY2415; J, K, OUM KY2416.
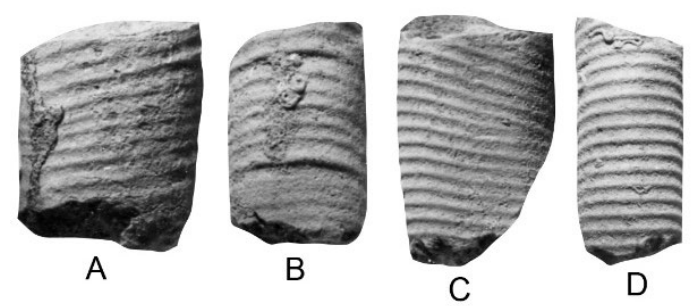

Fig. 12: A, B, Glyptoxoceras sp.; OUM KY2422; C, D, Scalarites sp.; OUM KY2286. 


\begin{tabular}{|c|c|c|}
\hline STAGE & SUBSTAGE & ZONE \\
\hline \multirow{3}{*}{ Coniacian } & Upper & $\begin{array}{c}\text { Paratexanites serratomarginatus } \\
\text { Gauthiceras margae }\end{array}$ \\
\hline & Middle & Peroniceras tridorsatum \\
\hline & Lower & Forresteria petrocoriensis \\
\hline \multirow{3}{*}{ Turonian } & Upper & $\begin{array}{l}\text { Prionocyclus germari } \\
\text { Subprionocyclus neptuni }\end{array}$ \\
\hline & Middle & Collignoniceras woollgari \\
\hline & Lower & $\begin{array}{l}\text { Mammites nodosoides } \\
\text { Fagesia catinus } \\
\text { Watinoceras devonense }\end{array}$ \\
\hline
\end{tabular}

Fig. 13: Turonian and Coniacian ammonite zones, Western Europe. 